\title{
Numerical Investigation of Smoke Extraction Methods in Large Storage Areas: Design Modifications
}

\author{
Ahmed Samir*, Abouelmagd Abdelsamie, Hatem Sadek \\ Department of Mechanical Power Engineering, Faculty of Engineering at El-Mattaria, Helwan \\ University, Masaken El-Helmia P.O., Cairo 11718, Egypt.
}

\begin{abstract}
The design of smoke extraction is very import part in any fire system design. Where an incorrect design of the smoke extraction strategy may lead to delay in the response of the fire extinguishing systems, which causes the high rate of loss of life and destruction of the building and its contents. This work, numerically investigates the effectiveness of a smoke exhaust strategy in a large storage area using a Computational Fluid Dynamics (CFD) package named Fire Dynamics Simulator (FDS), which will be used in this work in order to simulate fires in the store, a fire will be designed at certain conditions to mimic the fire loads expected in the storage. Smoke movement from the origin of the fire, and smoke contamination in the store are simulated in order to obtain the optimal design conditions of smoke extraction strategy. The parameters that influence the smoke extraction in large storage, which will be studied in this work are: 1) temperature distributions inside the space with different scenarios of the fire onset, 2) air velocity according to different fire scenarios, and 3) distribution of fresh and exhaust air outlet. The results of these simulations are presented and discussed.
\end{abstract}

\section{KEYWORDS}

Large Storage Areas, Fire Dynamics Simulation, Escape Time, Heat Release Rate.

*Corresponding author. Tel.: +201005375889. Email addresses: ahmedsamirmohamedhelmy@gmail.com 


\section{Nomenclature}

$\begin{array}{lll}\text { Symbol } & \text { Meaning } & \text { Unit } \\ C_{p} & \text { specific heat } & \mathrm{J} / \mathrm{kg} \cdot \mathrm{k} \\ \mathrm{D} & \text { density } & \text { Person/area } \\ \mathrm{g} & \text { gravity acceleration } & \mathrm{m} / \mathrm{s}^{2} \\ \dot{m}_{p} & \text { mass flow rate } & \mathrm{Kg} / \mathrm{s} \\ \mathrm{P} & \text { pressure } & \mathrm{Pa} \\ Q_{c} & \text { convective heat release rate } & \mathrm{KW} \\ \mathrm{T} & \text { temperature } & (\mathrm{K}) \text { or }\left({ }^{\circ} \mathrm{C}\right) \\ \mathrm{T}_{\mathrm{e}} & \text { travel Time } & \mathrm{min} \\ \mathrm{V} & \text { velocity } & \mathrm{m} / \mathrm{s} \\ \mathrm{Z} & \text { height above Fire } & \mathrm{M} \\ \lambda & \text { thermal conductivity } & \mathrm{W} / \mathrm{m} \cdot \mathrm{k} \\ \mu & \text { dynamic viscosity } & \mathrm{Pa} . \mathrm{s} \\ \rho & \text { density } & \mathrm{kg} / \mathrm{m}^{3} \\ \Delta \mathrm{T} & \text { temperature deviation } & (\mathrm{K}) \text { or }\left({ }^{\circ} \mathrm{C}\right)\end{array}$

\section{Subscripts}

2D

two dimensions

$3 \mathrm{D}$

three dimensions

\section{Abbreviations}

CFD computational fluid dynamics

FDS fire dynamics simulation

NIST national institute of standards and technology

LES large eddy simulation

DNS direct numerical simulation

RTE the radiative transport equation

CFM cubic feet per minute 
HVAC heating ventilation and air conditioning

DOE us department of energy

CIBSE chartered institution of building services engineers

HRR heat release rate

$\mathrm{CO} \quad$ carbon - oxide

PPM parts per million

\section{1-Introduction}

In case of fire in a building, the most mortality and injuries are often caused by smoke inhalation [1][2]. Smoke contains toxic and irritant gases which are the main cause of fatalities in fires. In addition, smoke reduces visibility, which makes it difficult for occupants to escape. The building smoke rises up from the origin of fire due to its buoyancy. As it rises up, it entrains more air and fills the upper region of the space forming an upper hot layer. Once the smoke layer is formed, its depth increases with time as more gases from the fire plume enter the hot layer [3]. A critical design parameter of the smoke management system is to keep the required minimum height of the smoke layer, which allows safe conditions for occupants to escape [4][5]. The key point of this strategy is to estimate the amount of smoke that should be extracted from the hot layer so that its thickness does not increase with time [6]. FDS is a computational fluid dynamics (CFD) solver for fire driven fluid flow developed by National Institute of Standards and Technology (NIST), which solves numerically Continuity equation, momentum equation and energy equation [7]. The formulation of the numerical equations and algorithm of the FDS can be found in the official manual and Technical Reference Guide [7], the main features can be summarized as follows,

1- Hydrodynamic Model

- The fundamental conservation equations of mass, momentum, and energy.

- Large Eddy Simulation (LES) approach for turbulence.

- Direct Numerical Simulation (DNS) if the numerical grid is fine enough.

- Limited to low Mach number flows.

2- Combustion Model

- Mixture fraction based, equilibrium chemistry model for combustion.

3- Thermal Radiation Transport Model

- The Radiative Transport Equation (RTE).

- Numerical methods.

- Finite difference scheme (1st-2nd order); predictor corrector time integrator (2nd order); rectangular Cartesian grid; multi-block grid. 


\subsection{Smoke Management System}

Smoke management is a term used to describe the methods implemented to passively or actively control the movement of smoke within the built environment in the interest of providing safety to occupants, fire fighters and property [8].

Smoke Management Methods include

- Passive Compartmentation;

- Dilution;

- Pressurization;

- Airflow;

- Buoyancy.

\subsection{Using CFD Simulation in Designing Smoke Management System in Buildings}

Hadjisophocleous and McCartney, 2005 [9] studied the effectiveness of a smoke exhaust system in a complex building by using the Computational Fluid Dynamics (CFD) models.

In order to simulate fires in the building a design fire was selected to represent the fire loads expected in the lobby area. In addition, studied and simulated the smoke movement from the origin of fire in the lobby and smoke contamination in the interconnected corridors in order to design the exhaust system to be capable of maintaining tenable conditions in the corridor used for evacuation.

A brief description of the main objectives of FDS is given in the following:

1- To determine the size and location of smoke exhaust vents required to maintain tenable conditions in the corridors and bridge;

2- To show conditions in the interconnected corridors as a result of a fire in the lobby.

\section{2-Scope of the Work and Computational Domain}

The volume of the store under investigation is $160 \times 142 \times 11 \mathrm{~m}^{3}$, due to the computational resources, using similarity laws. The store has used for archiving documents; it consists of the following regions/rooms:

- Storage area,

- Electrical panels rooms,

- Microfilm rooms,

- Shredding machines room.

The store includes eight fire escape doors; two of them $1.8 \times 5 \mathrm{~m}^{2}$ and the others has a dimension of $1.8 \times 3 \mathrm{~m}^{2}$. The smoke extraction system in the store according to its design and as built, consists of 39 smoke fans each of $16678 \mathrm{CFM}$, installed on the roof of the store. In 
addition, the exhaust air system consists of 41exhaust fans installed on the roof 6500 CFM/each. Moreover, the ventilation system inside the store consists of eight make up fans mounted to the right and left of the store 33477 CFM/each, as shown in Fig. 1. The top view of store under consideration is presented in Fig. 1a, whereas a schematic diagram shows the location of fans in the investigated case (store) is presented in Fig. 1b.

(a)

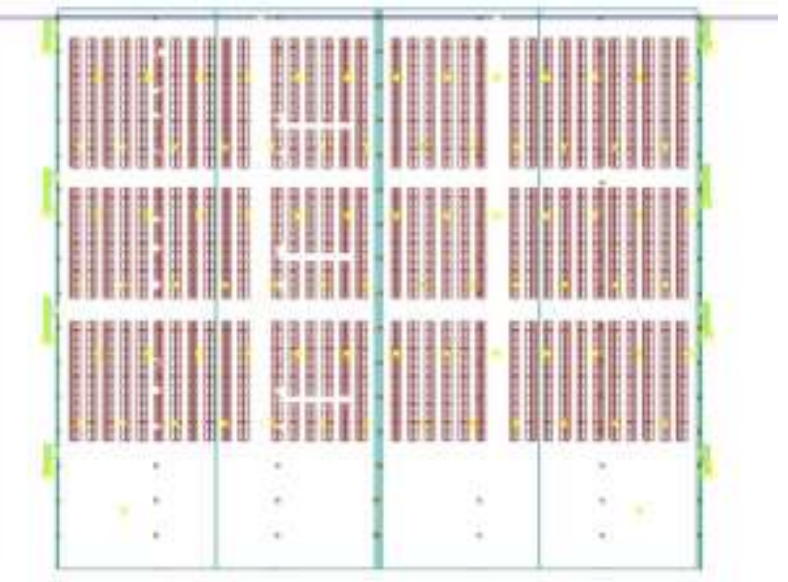

(b)

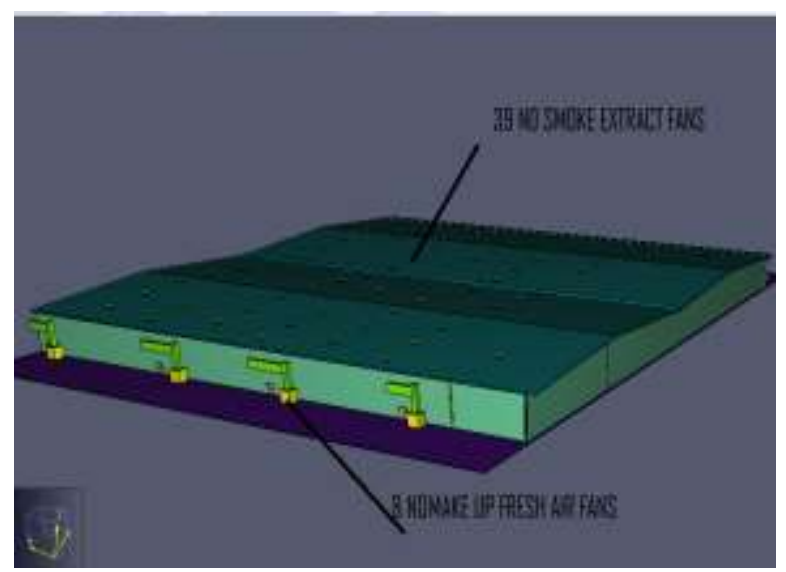

Fig. 1 Schematic diagram shows the location of fans in the investigated case. (a) Top view of the store under investigation. (b) 3D view of the store

\section{3- Modeling Assumptions and Concepts}

In this section the assumptions and concepts which are used in the simulation are reviewed.

\subsection{Fire and Smoke Scenarios}

At an ambient temperature $40^{\circ} \mathrm{C}$ and outside temperature $44^{\circ} \mathrm{C}$, there are 3 scenarios with the following fire location:

1- Scenario I, the fire is assumed to be initiated in the electrical room. Where, the fire material is suggested as a polyurethane chair. Fire is mimicked with heat of $2 \mathrm{MW}$ [10].

2- Scenario II assumed that the fire initiates in the mechanical room, and the fire material suggested as a polyurethane sofa, fire is mimicked with heat of $3 \mathrm{MW}$ [10].

3- Scenario III: Racks area. The fire material suggested as wood construction, Fire is replaced with heat of $6 \mathrm{MW},[10]$.

\subsection{Tenability Criteria}

Tenable environment is one in which the products of combustion, including heat, smoke, and toxic gasses, are at levels that are not life threatening or adversely impact the ability to egress.

- Maximum air temperatures of $70^{\circ} \mathrm{C}$ are allowed for 6 minutes [11].

- Door and wall must be visible from $10 \mathrm{~m}$ distance [11]. 
- CO-concentration averaging 1500 PPM or less for the first 6 minutes of the exposure [11].

\subsection{Estimated Evacuation Time}

The population will use all exit facilities in the optimum balance; all occupants start egress at the same time. The parameters of the calculation are presented in Table 1.

Table 1: Details of calculation parameters [12]

\begin{tabular}{|c|c|}
\hline Maximum escape route & $117 \mathrm{~m}$ \\
\hline Egress door effective width & $(1.80 \mathrm{~m}-0.1 \mathrm{~m}=1.7 \mathrm{~m})$ \\
& $0.1 \mathrm{~m}$ for door thickness \\
\hline Occupant load (Density) & $27.9\left(\mathrm{~m}^{2} /\right.$ person $)[13]$ \\
\hline
\end{tabular}

The speed of people along the line of travel is calculated by the following equation,[10]

$$
S=K-a K D
$$

Where $S, D$ and $K$ are the speed along the line of travel, density (person/unit area), and constant respectively where $K=K s=1.4$ [12]. In this equation, a constant $a=0.266$ when calculating speed in meter per second and density in person per square meter,

$$
\begin{gathered}
\mathrm{D}=1 / 27.9=0.0358(\text { persons } / \text { unit area }) \\
\mathrm{S}=1.4-(0.266 \times 1.4 \times 0.0358), \\
\mathrm{S}=1.38 \mathrm{~m} / \mathrm{s}=83 \mathrm{~m} / \mathrm{min} .
\end{gathered}
$$

the calculated speed is more than maximum exit flow speed so it selected to be $1.19 \mathrm{~m} / \mathrm{s}$ or 60 $\mathrm{m} / \mathrm{min}[12]$.

\subsubsection{Walking Time for Longest Escape Route}

The walking time taken to travel along the longest exit route is the travel time $T_{e}$, which is computed as ratio of the longest exit route to the travel speed of passenger [12]. From Table 1 and from the previous section, $\mathrm{T}_{\mathrm{e}}=117 / 60=1.95 \mathrm{~min}$.

\subsubsection{Total Evacuation Time to Outside}

The total evacuation time to outside, $\mathrm{T}_{\mathrm{ev}}$, is computed as the summation of the travel time, $\mathrm{T}_{\mathrm{e}}$ and the delay time $\mathrm{T}_{\mathrm{d}}$, which is shouldn't exceed $2 \min$ [12]. Therefore, in the current work, $\mathrm{T}_{\mathrm{ev}}=1.95+2=3.95 \mathrm{~min}$. Consequently, the results of FDS will be taken after 4 min of fire occurred.

\subsection{Sprinklers Effect}

US Department of energy (DOE) assume both automatic systems fail and that the fire department doesn't respond [12]. A fire that starts, while either the fire alarm system or the 
sprinkler system (in turn) is rendered ineffective. But for ensure that the resulting losses are not catastrophic and the fire system will work properly. The sprinklers effect in this scenario will take into consideration [14]. the sprinkler that was used in the model with the following parameters,

- $\mathrm{K}_{\text {Factor }}=5.6$,

- Temperature $=68 \mathrm{C}^{\circ}$

\subsection{Modeling Software}

- FDS shall be utilized by PYROSIM 2020.

- REVIT 2019.

\section{4- Impact of Using Different Scenario}

In this section, the impact of using different scenarios (Sec. 3.1) will be discussed in details.

\subsection{Electrical panels room scenario (Scenario I)}

Additional numerical calculations as per Chartered Institution of Building Services Engineers (CIBSE Guide E), are carried out to verify that the ventilation methodologies provided are suitable for the intended purposes of smoke extraction. These calculations are supplementary and are supporting the FDS analysis conducted. The FDS analysis results are indicated later in this part for electrical panels room, after the calculations. Figure 3 shows the essential requirements for smoke control.

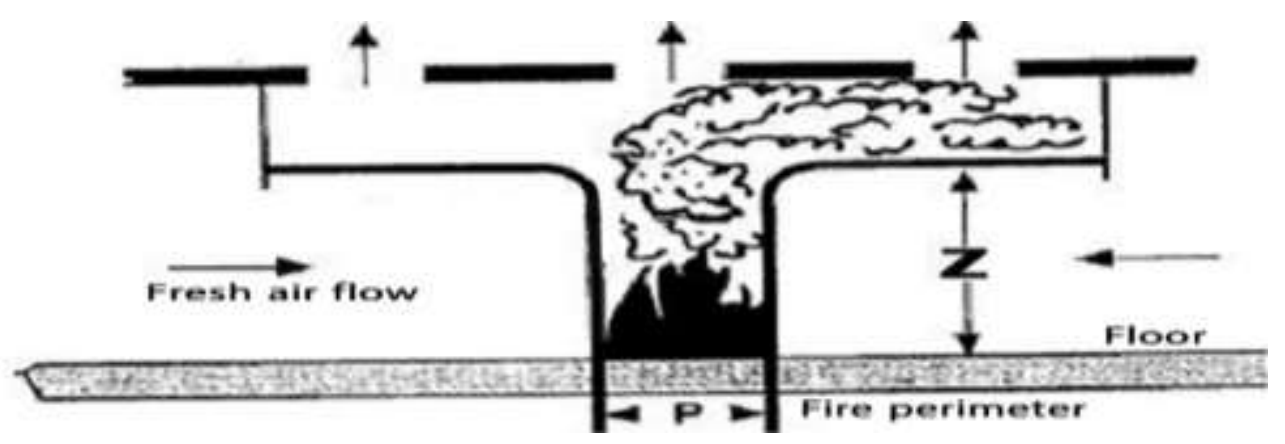

Fig. 2 The essential requirements for smoke control for Scenario I [15].

In this scenario, the source of fire is considered as the electrical equipment, the method used as per CIBSE Guide E, Section 10.8.3 in Ref. [10]. The fire calculation is performed based on the finite area source- circle or rectangle. Based on this finite area source, the formula for mass flow calculation is

$$
\dot{m}_{p}=0.188 \mathrm{P} \times \mathrm{Z}^{3 / 2},
$$

where $\dot{m}_{p}, \mathrm{Z}$ and $\mathrm{P}$ are the mass flow by entrainment in $\mathrm{kg} / \mathrm{s}$, height above the base of the fire equals $10 \mathrm{~m}$ and the perimeter of fire source equals $4 \mathrm{~m}$ respectively. Substituting the 
respective abovementioned values in the Eq. (2), the value of the mass flow rate is $23.78 \mathrm{~kg} / \mathrm{s}$. Also, the average temperature of the plume is given by [15] is calculated as

$$
\mathrm{T}_{\mathrm{s}}-\mathrm{T}_{\mathrm{o}}=\mathrm{Q}_{\mathrm{p}} /\left(\dot{m}_{p} \times \mathrm{C}_{\mathrm{p}}\right),
$$

where $T_{s}, T_{o}, Q_{p}$ and $C_{p}$ are the average fire plume temperature in Kelvin, the absolute ambient temperature ( 313 Kelvin), the total heat release rate $=2000 \mathrm{~kW}$ and the specific heat of air $=1 \mathrm{~kJ} / \mathrm{kg} / \mathrm{k}$ respectively. Substitute these values in Eq. (3), $\mathrm{T}_{\mathrm{s}}$ found to be $397 \mathrm{~K}$. The required air volumetric flow rate for smoke extract fan, based on the above calculated temperature and mass flow rate values is as indicated below as in Ref. [15],

$$
\mathrm{V}=\left(\dot{m}_{p} \times \mathrm{T}_{\mathrm{s}}\right) /\left(\rho_{\mathrm{s}} \times \mathrm{T}_{\mathrm{o}}\right)
$$

where $\rho_{\mathrm{s}}, \dot{m}_{p}, \mathrm{~T}_{\mathrm{s}}$ and $\mathrm{T}_{\mathrm{o}}$ are the smoke density $1.2 \mathrm{Kg} / \mathrm{m}^{3}$, the mass flow rate by entrainment, the average plume temperature and the absolute ambient air temperature respectively. Substituting the respective abovementioned values in the Eq. (4), the volume flow rate V equals to $25.13 \mathrm{~m}^{3} / \mathrm{s}$ (53248 CFM). Therefore, the smoke extract fans must produce at least $25.13 \mathrm{~m}^{3} / \mathrm{s}$ flow rate.

Thus, it can be concluded that the extract fans provided for the electrical panel room will be sufficient to provide necessary smoke extraction of electrical panels room.

\subsubsection{Grid size selection for Scenario I}

The grid size is selected to be small near the fire zone, about $0.3 \mathrm{~m}$ and $0.6 \mathrm{~m}$ away from fire. The total grid points have $(317,248,20)$ regions in $(X, Y, Z)$ directions respectively, giving a total number of calculation cells as 1,572,320. The location of the fire location in Scenario I, displayed in Fig. 3.

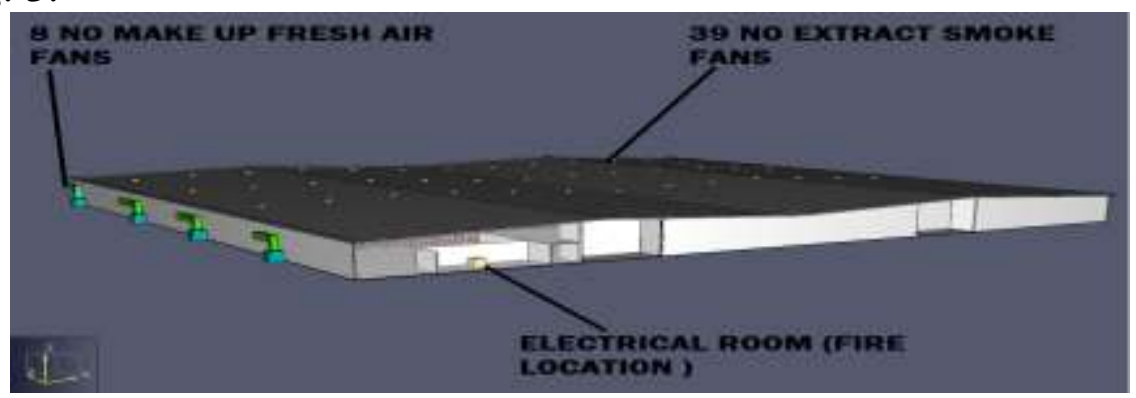

Fig. 3 The fire location for electrical panels room (Scenario I).

\subsubsection{Results of FDS simulation for Scenario I}

The FDS analysis simulation done using the parameters mentioned in the previous sections (Sec. 3); the results of this simulation are summarized below. Figure 4 shows the escape paths $1 \& 2$ in full scale area of the store, whereas Fig. 5 illustrates two sections for each escape path: path 1 (Fig. 5 left), and path 2 (Fig. 5 right). 


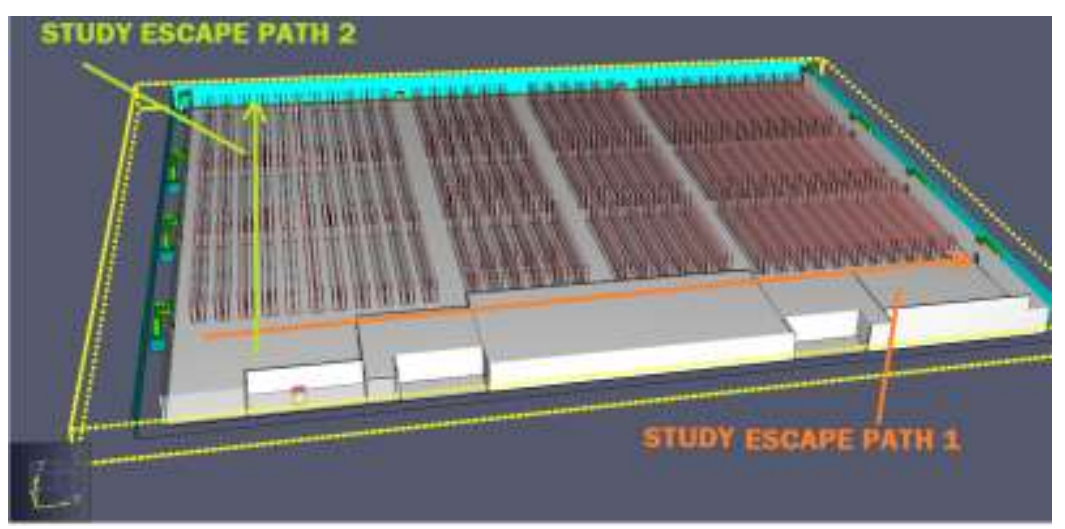

Fig. 4 Escape paths $1 \& 2$ in full scale area of the store (Scenario I).

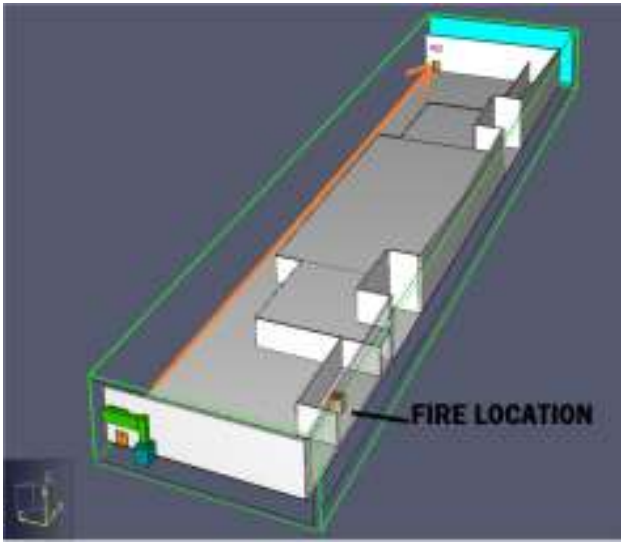

(a) Escape path 1

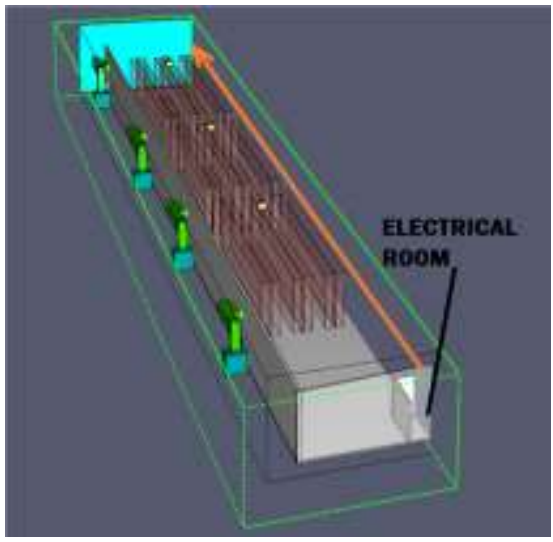

(b) Escape path 2

Fig. 5 Schematic diagram shows section for escape path $1 \&$ escape path 2 (Scenario I).

The Following figures shows the three most important parameters, temperature, Visibility, and $\mathrm{CO}$ Concentration at various locations. Figure 6 shows the heat release rates in fires as a function of time, Fig. 7 illustrates the maximum temperature in escape route as a function of time, and Fig. 8 represents the visibility in escape route as a function of time.

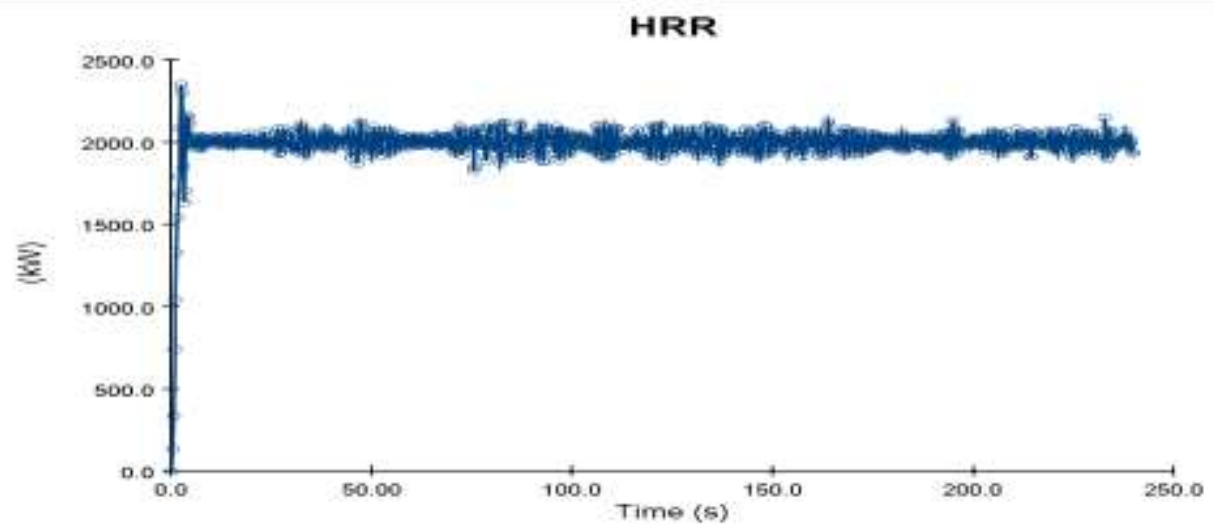

Fig. 6 The heat release rates in fires as a function of time (Scenario I). 


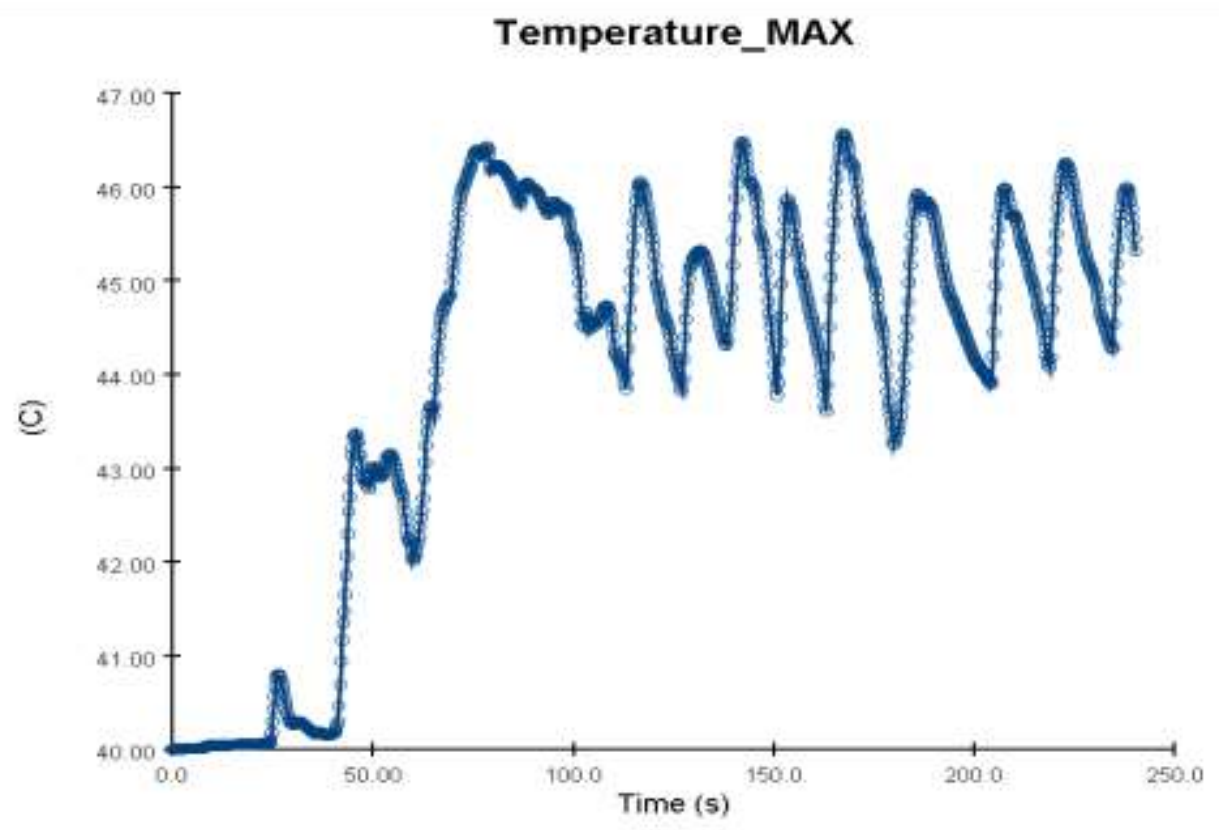

Fig. 7 The maximum temperature in escape route as a function of time (Scenario I).

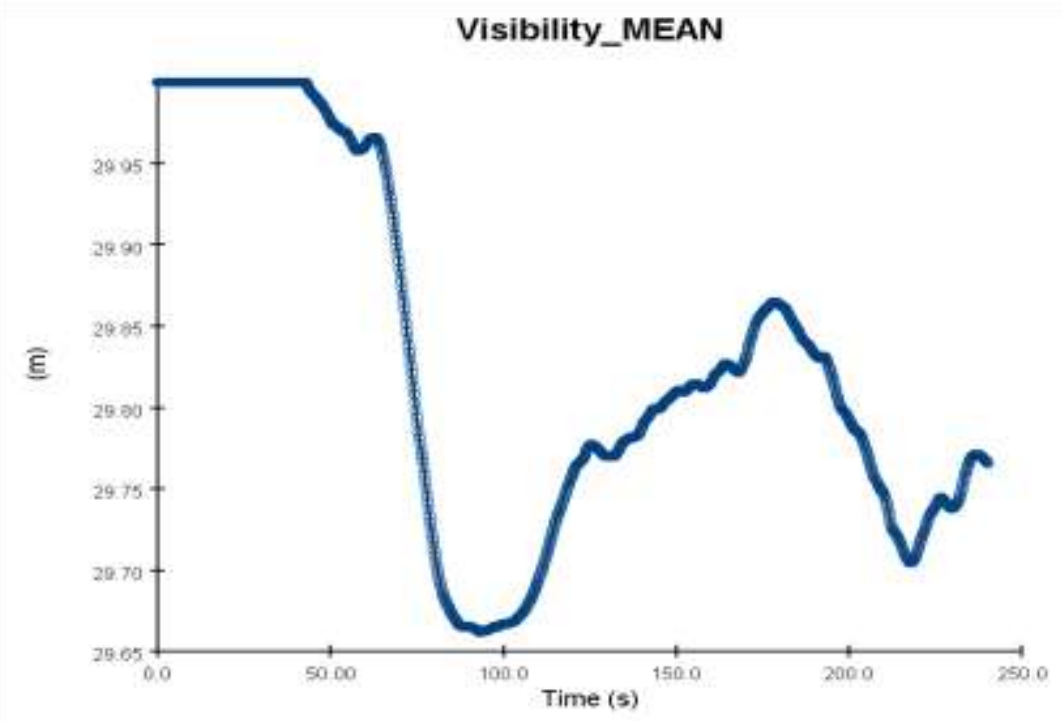

Fig. 8 The visibility in escape route as a function of time (Scenario I).

Velocity, smoke, and temperature distribution over the store are shown in Figs. 9, 10, and 11, respectively. The make-up fresh air distribution is illustrated by Fig. 9 a, and Fig. 9b, which are the top and side view, respectively. Also, the smoke path is presented in Fig. 10a and Fig. $10 \mathrm{~b}$, which are at different building orientations. 


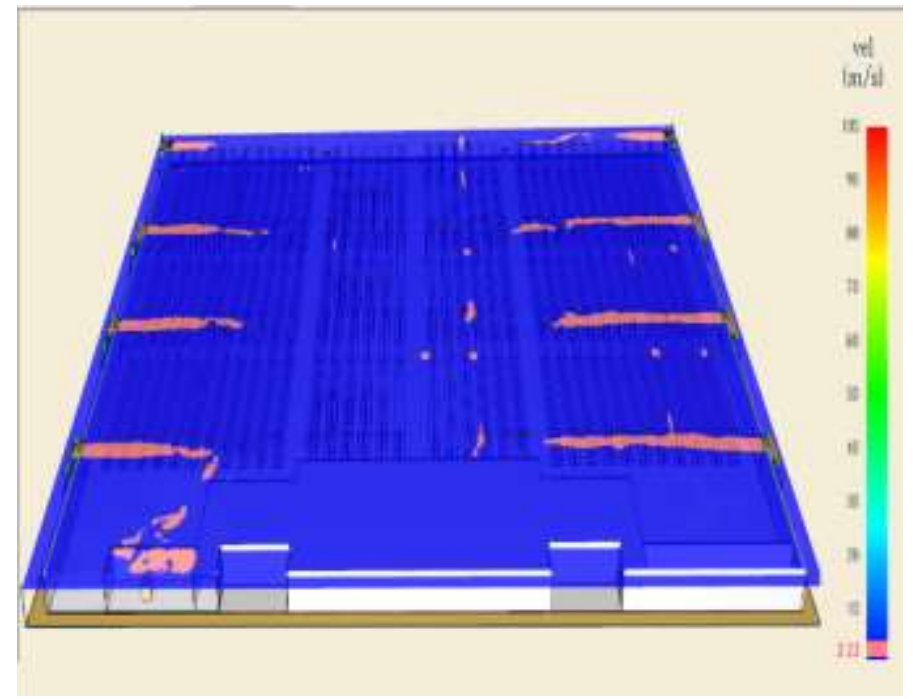

(a) Top view

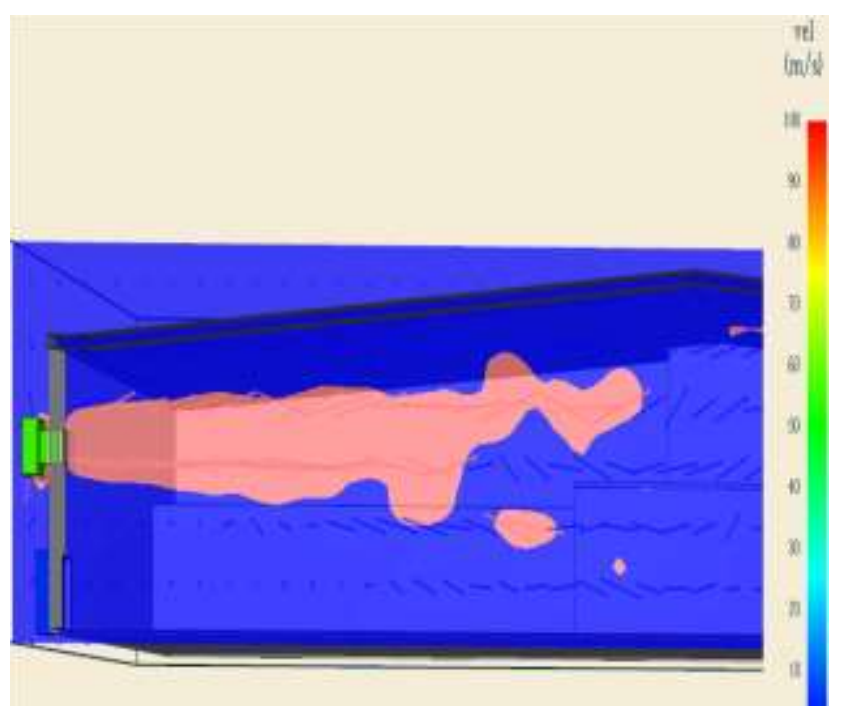

(b) Randomly selected side-section

Fig. 9 Velocity distribution of make-up fresh air fans (Scenario I).

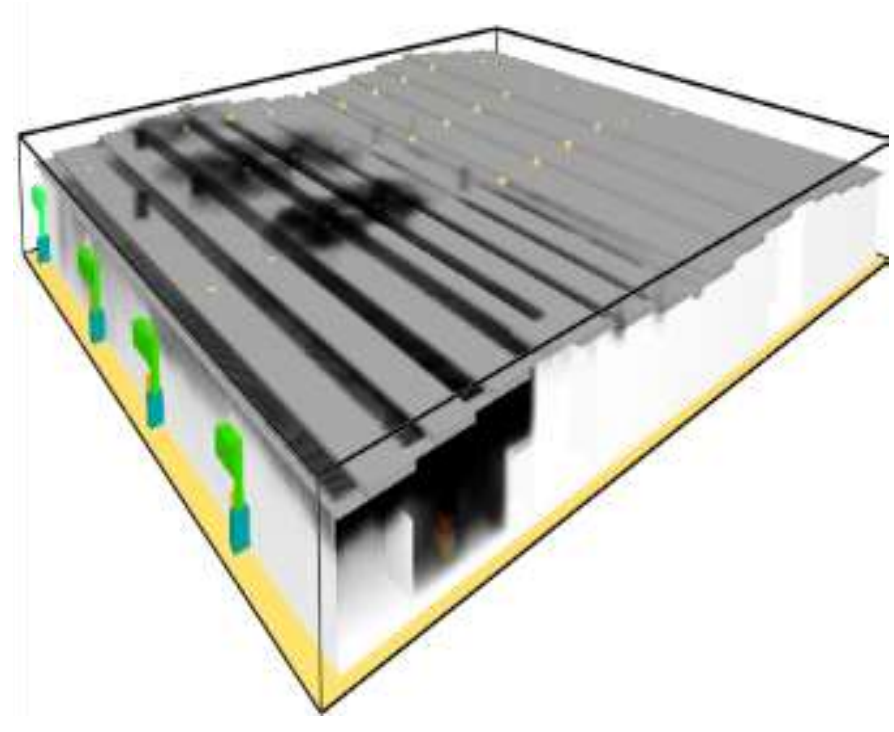

(a) Shot 1

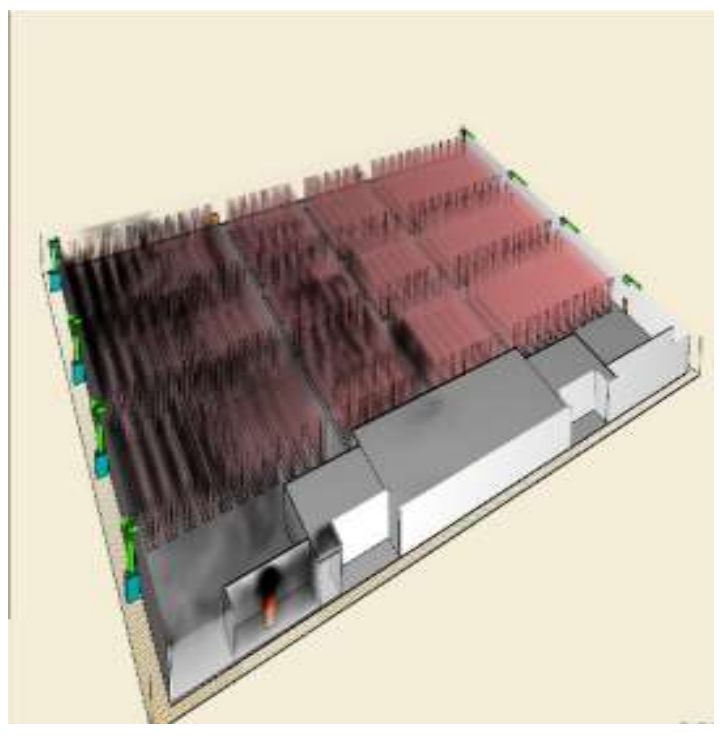

(b) Shot 1

Fig. 10 Schematic diagram shows the smoke view over the store during the fire (Scenario I).

Figures $11 \mathrm{a}$ and $11 \mathrm{~b}$ show the average temperature in escape path 1 (maximum temperature $42.35^{\circ} \mathrm{C}$ ), and the average temperature in escape path 2 (maximum temperature is $41.96^{\circ} \mathrm{C}$ ), respectively. 


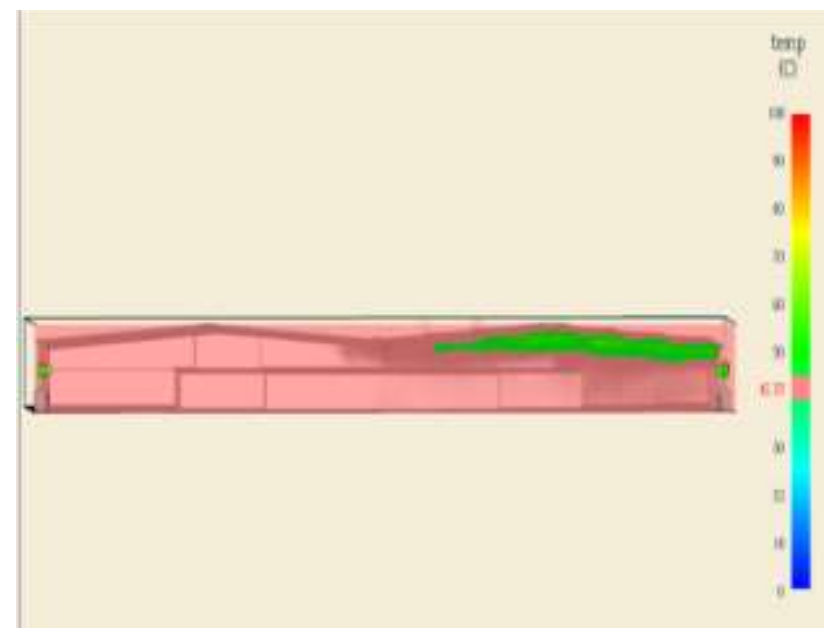

(a) Average temperature in escape path 1

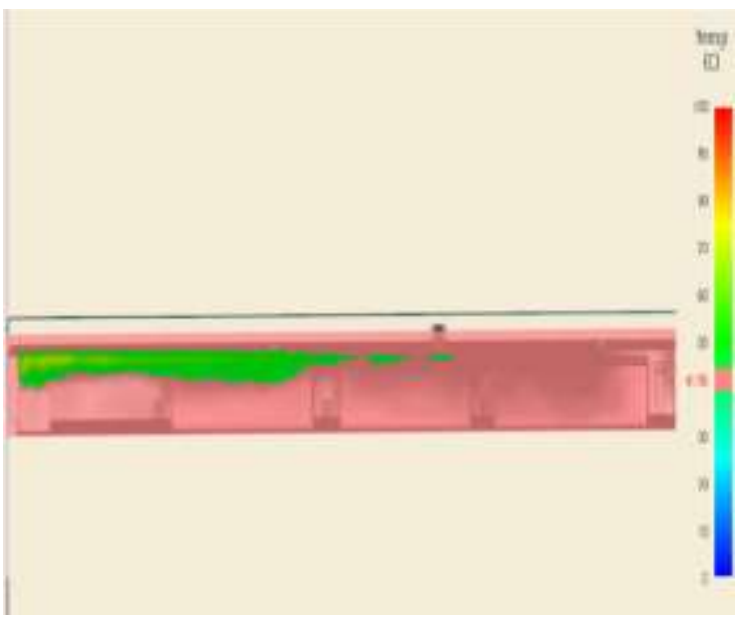

(b) Average temperature in escape path 2

Fig. 11 Cut planes shows the average temperature during the fire (Scenario I).

The visibility is presented in Figs. 12a and Fig. 12b, which shows the visible escape distance above the ground for path 1 . The escape distance for path 2 can be found in Fig. 13.

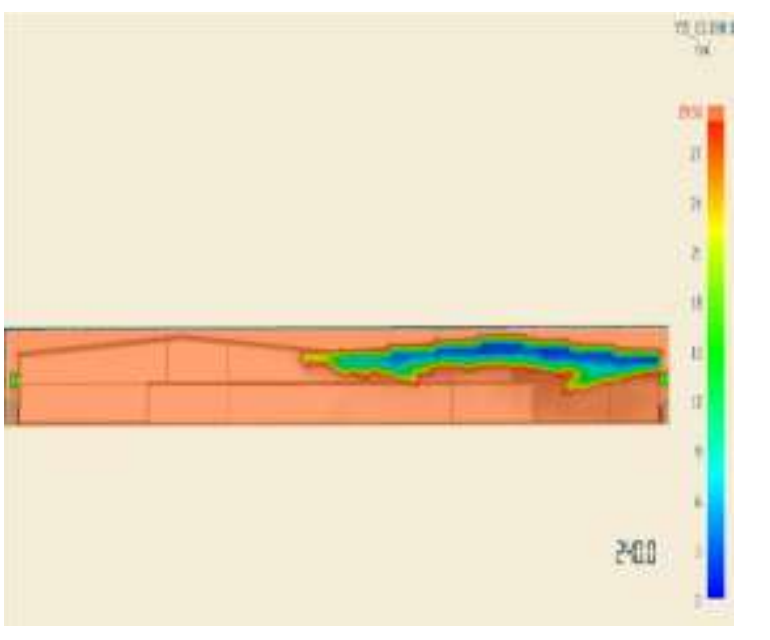

(a) 2d Cuts plane

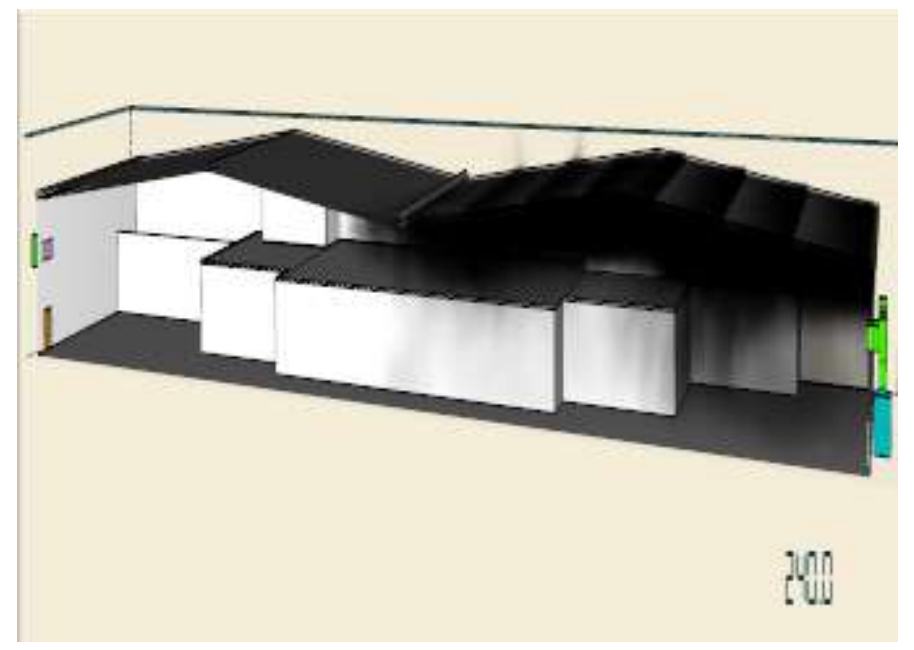

(b) different orientation

Fig. 12 Schematic diagram shows the visible distance for Escape path 1 (Scenario I). 


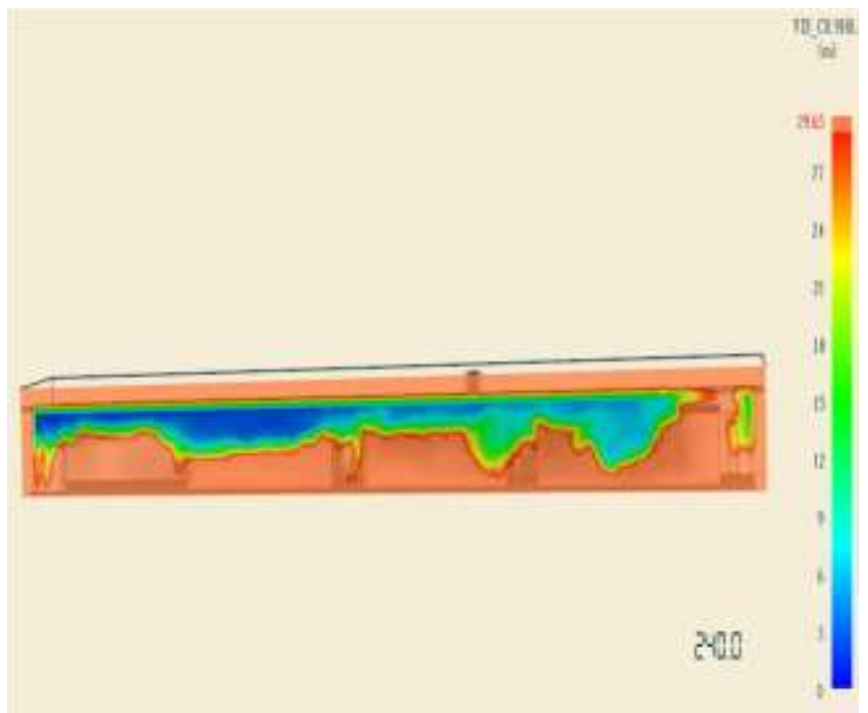

(a) shot 1

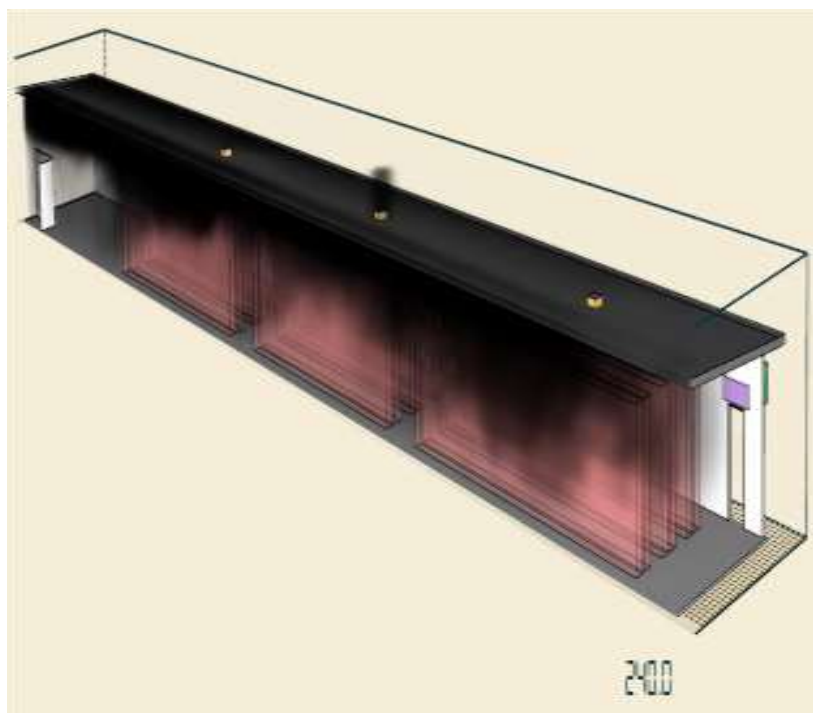

(b) shot 2

Fig. 13 Schematic diagram shows the visible distance for Escape path 2 (Scenario I).

Figures 14.a,14. b shows the CO concentration in parts per million for escape path 1 , and the $\mathrm{CO}$ concentration in parts per million for escape path 2 respectively.

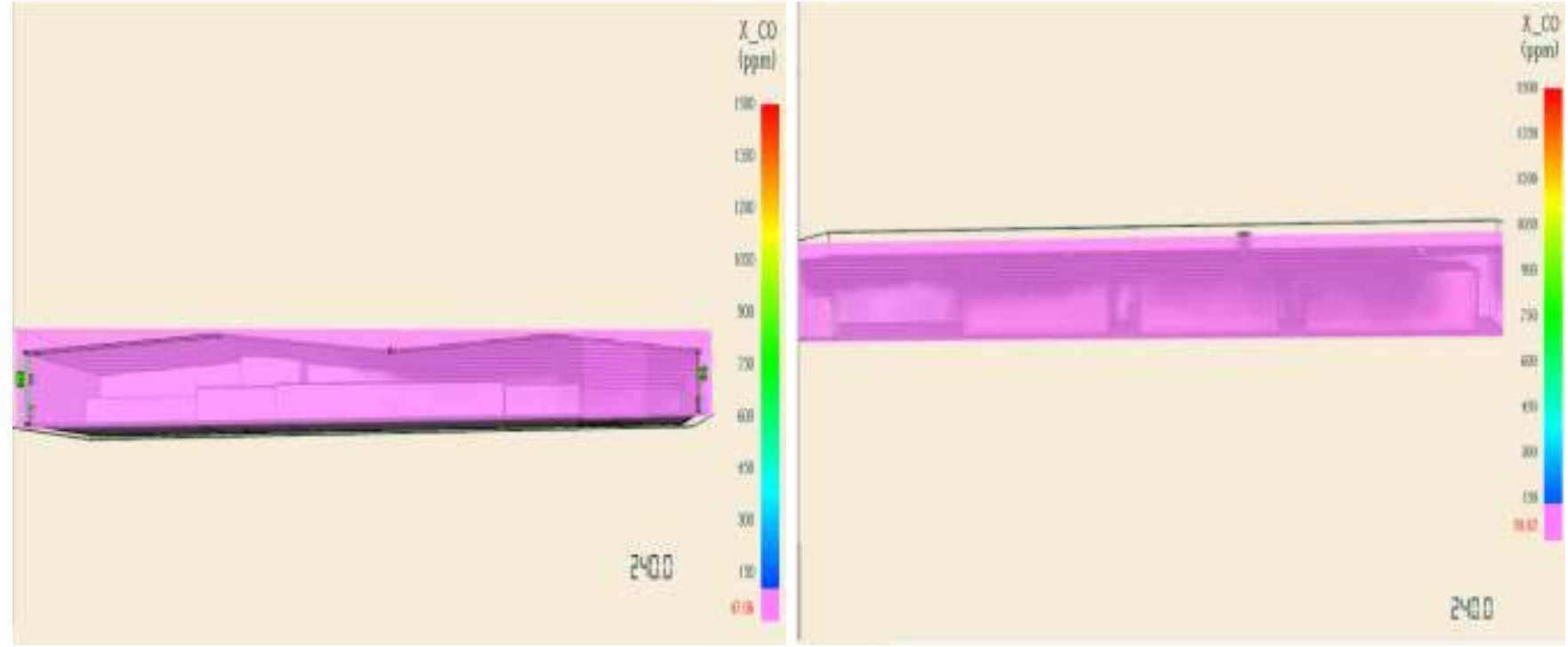

(a) For escape path 1

(b) For escape path 2

Fig. 14 Schematic diagram shows the $\mathrm{CO}$ concentration in parts per million during the fire.

\subsubsection{Conclusion on Scenario I}

Based on the FDS analysis model, the table below summarizes NFPA 92-2018 requirements. As seen from the summary, the values of various parameters are within the tolerable limits as per the standard as shown as Table 2. 
Table 2: NFPA 92-2018 requirements for Scenario I.

\begin{tabular}{|c|c|}
\hline NFPA 92 Requirements & Results Achieved \\
\hline $\begin{array}{c}\text { Maximum air temperatures of } 60^{\circ} \mathrm{C} \text { are allowed for a few } \\
\text { seconds. }\end{array}$ & Max $47^{\circ} \mathrm{C}$ \\
\hline Door and wall should be visible from $10 \mathrm{~m}$ distance. \\
\hline $\begin{array}{c}\text { Co concentration Averaging } 1500 \text { ppm or less for the first } \\
6 \text { minutes of the exposure. }\end{array}$ & $29.5 \mathrm{M}$ \\
\hline
\end{tabular}

Based on this summary we can conclude that the mechanical ventilation system using the smoke extract fans and make-up fans is sufficient considering the parameters defined within this work.

\subsection{Mechanical Room Scenario (Scenario II)}

In this scenario, the source of fire is considered as mechanical equipment, the method used as per CIBSE Guide E, Section 10.8.3 in Ref. [15]. The fire calculation is performed based on the finite area source-circle or rectangle model similar to pervious section (Scenario I, Eq. (2)) the only difference is the perimeter of fire source, which equals $10 \mathrm{~m}$ here. Substituting the respective abovementioned values in the Eq. (2), the value of the mass flow rate is $59.45 \mathrm{~kg} / \mathrm{s}$. Also, the average temperature of the plume is given by [13] is calculated as similar to Eq. (3) but with different values, where here, the total heat release rate $=3000$. Substitute these values in Eq. (3), $\mathrm{T}_{\mathrm{s}}$ found to be $364 \mathrm{~K}$. The required air volumetric flow rate for smoke extract fan, based on the above calculated temperature and mass flow rate values is computed using Eq. (4), where $\mathrm{V}$ equals to $57.61 \mathrm{~m}^{3} / \mathrm{s}$ (122068 CFM). Therefore, the smoke extract fans must produce at least $57.61 \mathrm{~m}^{3} / \mathrm{s}$ flow rate. Thus, it can be concluded that the extract fans provided for the mechanical room will be sufficient to provide necessary smoke extraction of mechanical room. (FDS simulation for this Scenario is not shown here because of the paper length)

\subsubsection{Conclusion on Scenario II}

Based on the FDS analysis model, the table below summarizes NFPA 92-2018 requirements. As seen from the summary, the values of various parameters are within the tolerable limits as per the standard as shown as Table 3.

Table 3: NFPA 92-2018 requirements for Scenario II.

\begin{tabular}{|c|c|}
\hline NFPA 92 Requirements & Results Achieved \\
\hline $\begin{array}{c}\text { Maximum air temperatures of } 60^{\circ} \mathrm{C} \text { are allowed for } \\
\text { a few seconds. }\end{array}$ & $\operatorname{Max~} 49^{\circ} \mathrm{C}$ \\
\hline Door and wall should be visible from $10 \mathrm{~m}$ distance. & $18 \mathrm{~m}$ \\
\hline $\begin{array}{c}\text { Co concentration Averaging } 1500 \mathrm{ppm} \text { or less for } \\
\text { the first } 6 \text { minutes of the exposure. }\end{array}$ & $\operatorname{Max} 80 \mathrm{ppm}$ \\
\hline
\end{tabular}


Based on this summary we can conclude that the mechanical ventilation system using the smoke extract fans and make-up fans is sufficient considering the parameters defined within this work.

\subsection{Racks Area Scenario (Scenario III)}

In this scenario, the source of fire is considered as wood construction, the method used as per CIBSE Guide E, Section 10.8.3 in Ref. [15]. The fire calculation is performed based on the finite area source-circle or rectangle model similar to pervious section (Scenario I, Eq. (2)) the only difference is the perimeter of fire source, which equals $10 \mathrm{~m}$ here. Substituting the respective abovementioned values in the Eq. (2), the value of the mass flow rate is $59.45 \mathrm{~kg} / \mathrm{s}$. Also, the average temperature of the plume is given by [13] is calculated as similar to Eq. (3) but with different values, where here, the total heat release rate $=6000 \mathrm{~kW}$. Substitute these values in Eq. (3), $\mathrm{T}_{\mathrm{s}}$ found to be $413.92 \mathrm{~K}$. The required air volumetric flow rate for smoke extract fan, based on the above calculated temperature and mass flow rate values is computed using Eq. (4), where V equals to $65.52 \mathrm{~m}^{3} / \mathrm{s}$ (138830 CFM). Therefore, the smoke extract fans must produce at least $65.52 \mathrm{~m}^{3} / \mathrm{s}$ flow rate. Thus, it can be concluded that the extract fans provided for the racks area will be sufficient to provide necessary smoke extraction for this area.

\subsubsection{Grid Size Selection for Racks Area (Scenario III)}

Model grid size is selected to be small near fire of about $0.3 \mathrm{~m}$ and $0.6 \mathrm{~m}$ away from fire. The model grid has $(296,249,24)$ regions in $(X, Y, Z)$ directions respectively, giving a total Number of calculation cells as 1,694,548.

\subsubsection{Results of FDS Simulation (Scenario III)}

The FDS analysis simulation done using the parameters mentioned in the previous sections (Sec. 3); the results of this simulation are summarized below. Figure 15 shows the location of the fire location in scenario III and the escape paths $1 \& 2$ in full scale area of the store, whereas Fig. 16 illustrates two sections for each escape path: path 1 (Fig. 16 left), and path 2 (Fig. 16 right).

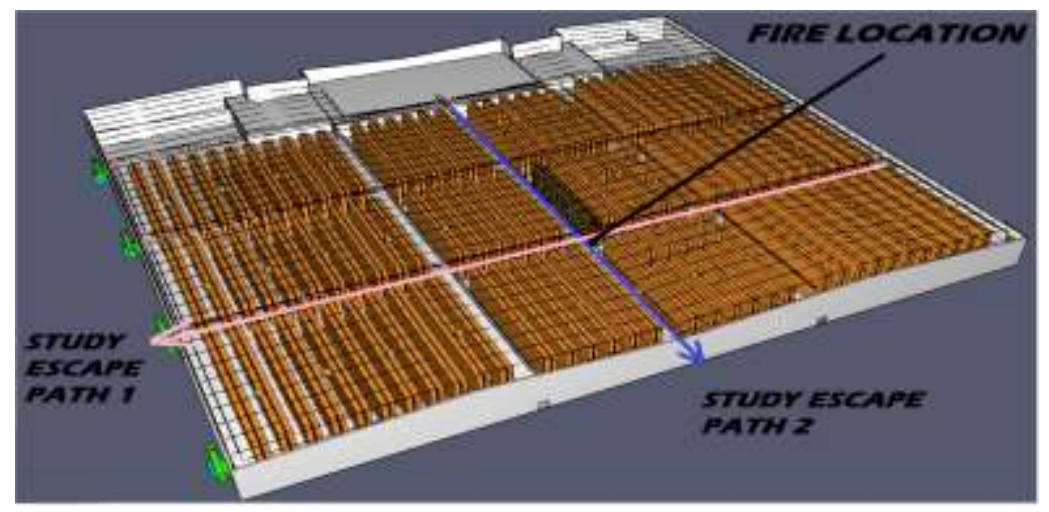

Fig. 15 The fire location for racks area \&Escape paths $1 \& 2$ in full scale area of the store. 


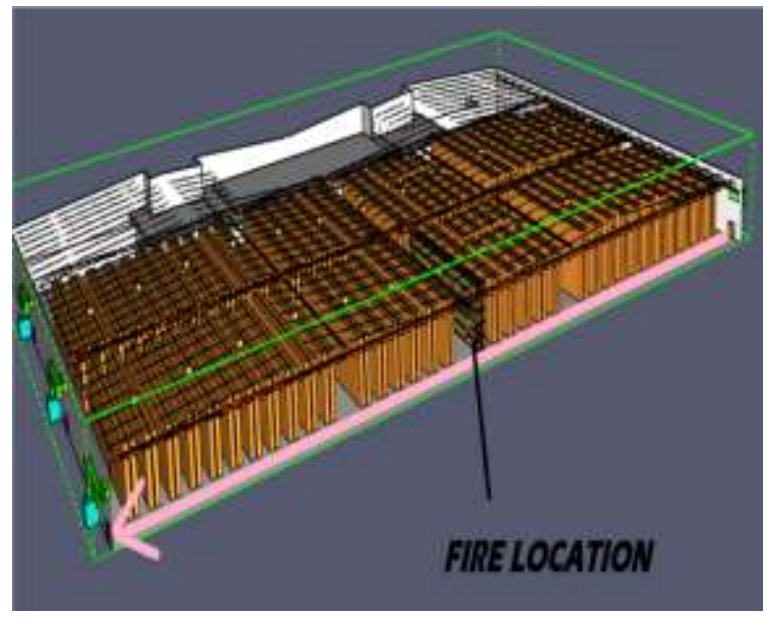

(a) Escape paths 1

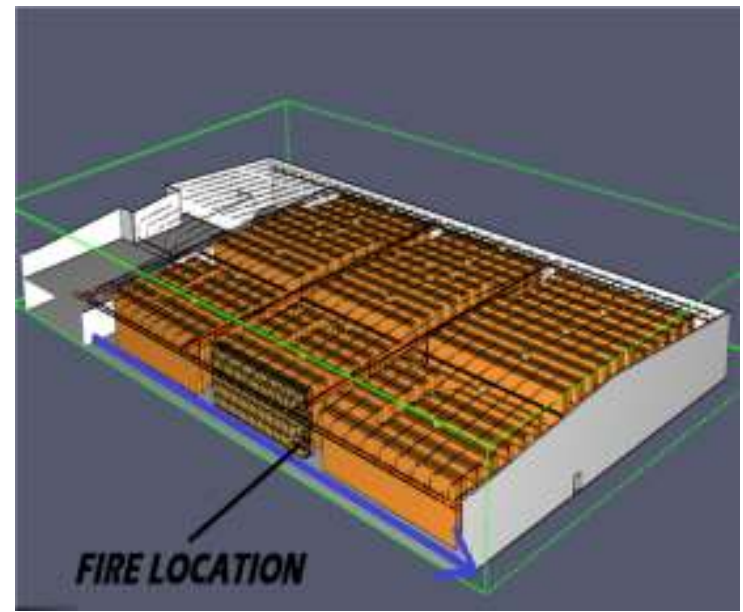

(b) Escape paths 2

Fig. 16 Schematic diagram shows section for escape path $1 \&$ escape paths 2 (Scenario III).

The Following figures shows the three most important parameters, temperature, visibility, and $\mathrm{CO}$ concentration at various locations. Figure 17 shows the heat release rates in fires as a function of time, Fig. 18 illustrates the maximum temperature in escape route as a function of time, and Fig. 19 represents the visibility in escape route as a function of time.

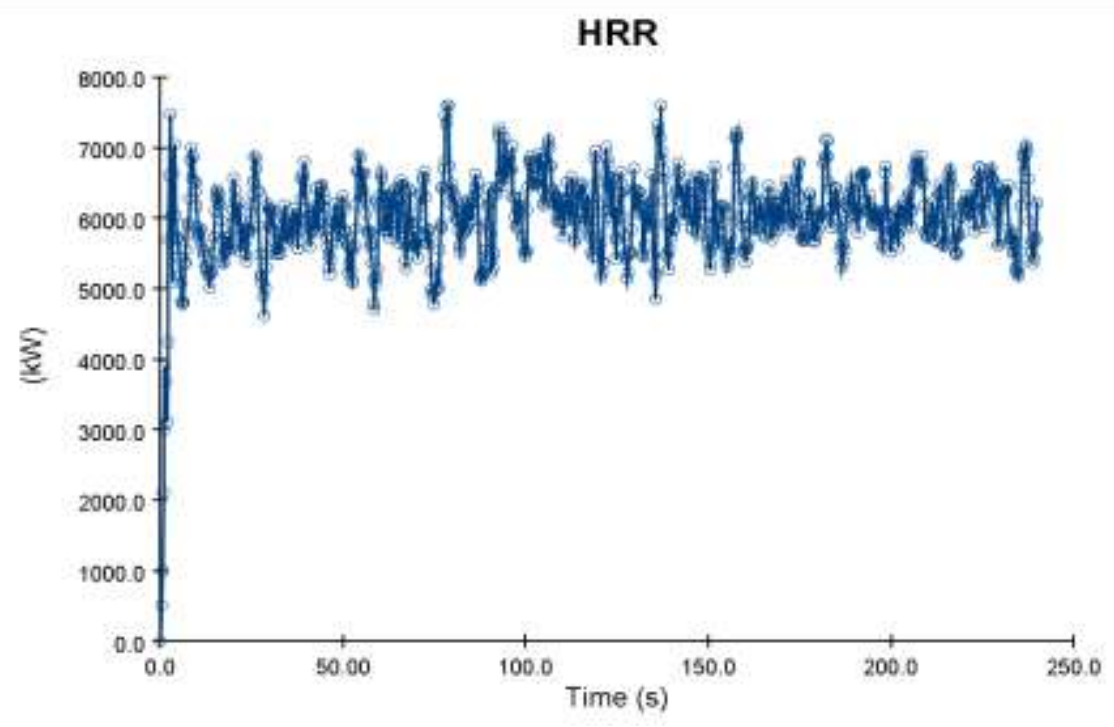

Fig. 17 The heat release rates in fires as a function of time (Scenario III). 


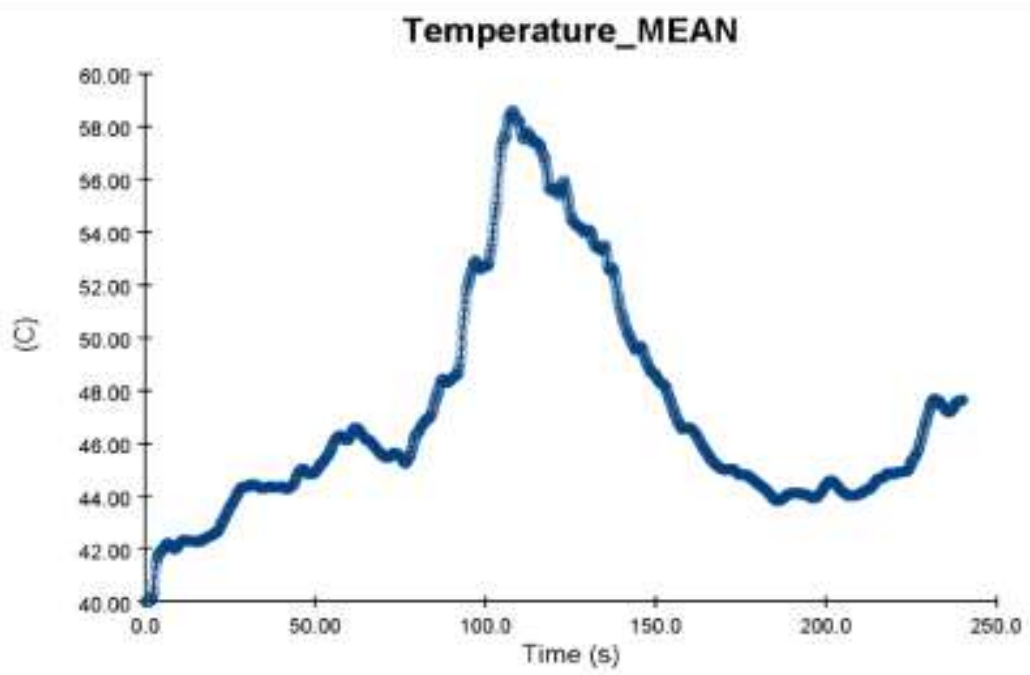

Fig. 18 The maximum temperature in escape route as a function of time (Scenario III).

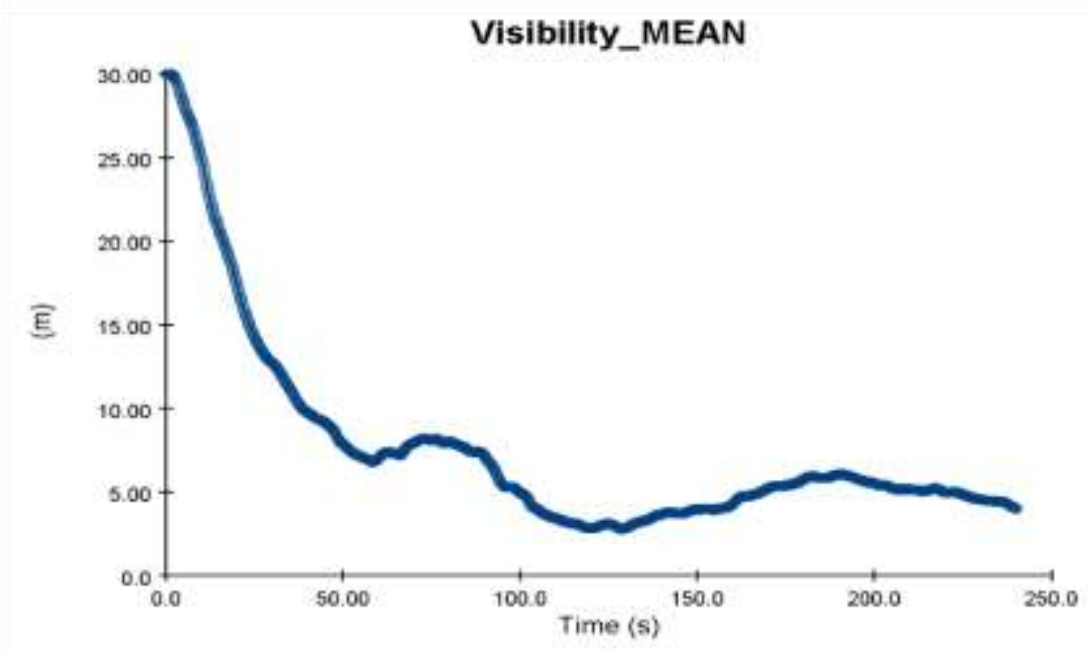

Fig. 19 The visibility in escape route as a function of time (Scenario III).

Velocity, smoke, and temperature distribution over the store are shown in Figs. 20, 21, and 22, respectively. The make-up fresh air distribution is illustrated by Fig. 20 a, and Fig. 20b, which are the top and side view, respectively. In additional the velocity for smoke extract fans during the fire illustrated by Fig .21a, and Fig 21b. Also, the smoke path is presented in Fig. 22a and Fig. 22b, which are at different building orientations. 


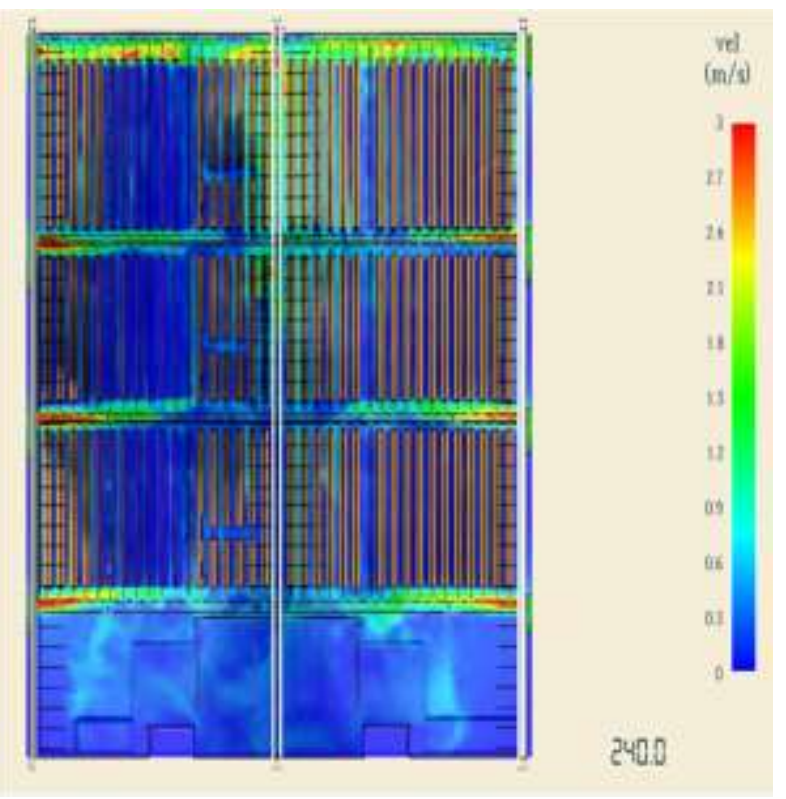

(a) Top view

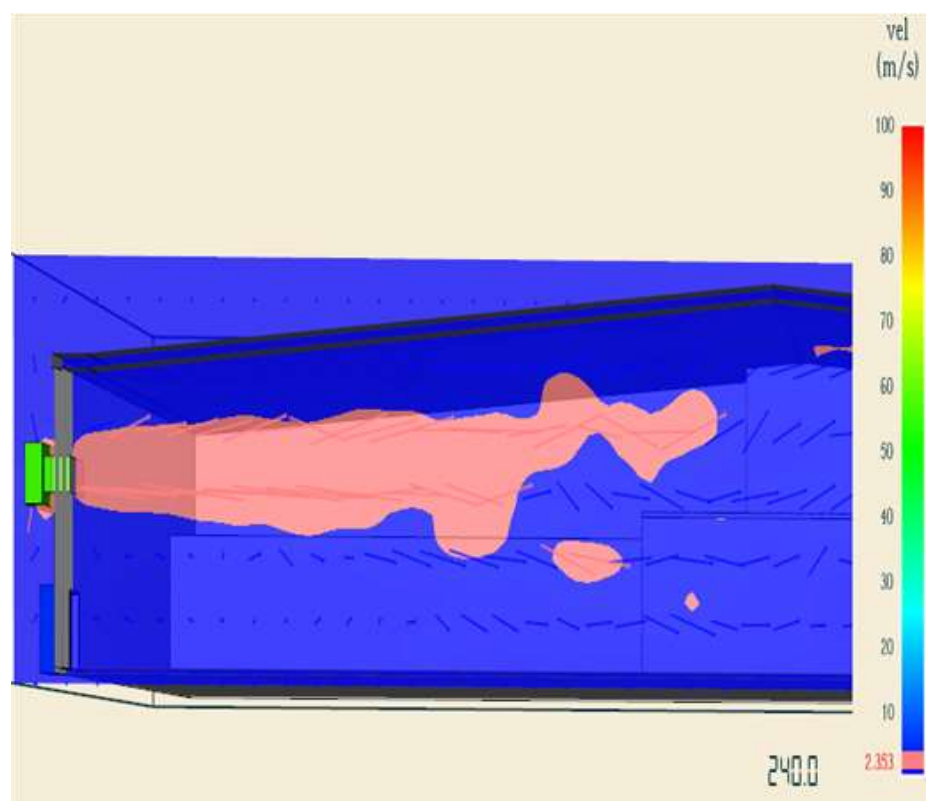

(b) Randomly selected side-section

Fig. 20 Velocity distribution of make-up fresh air fans (Scenario III).

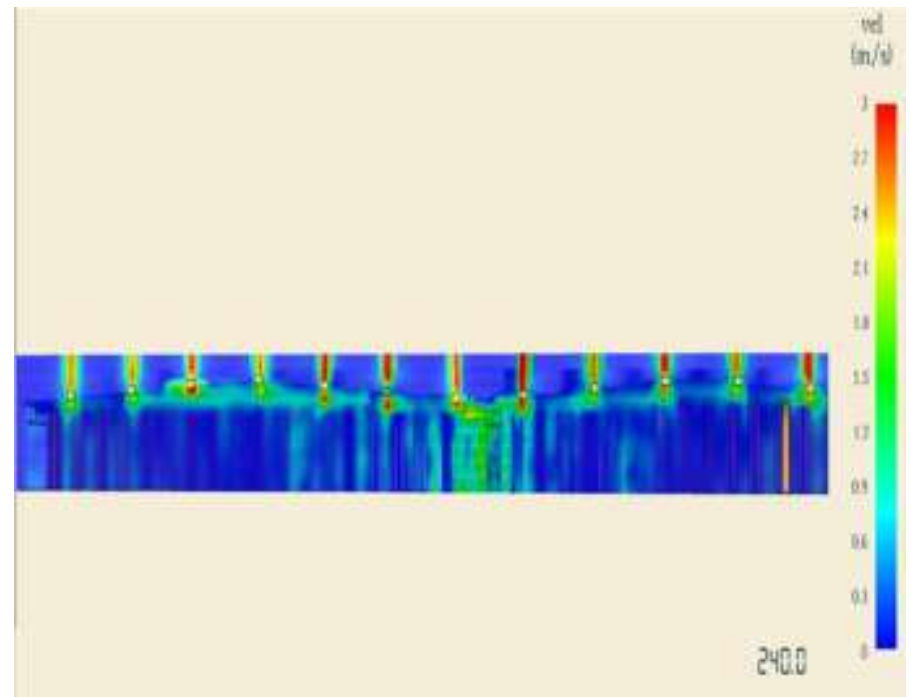

(a) Shot 1

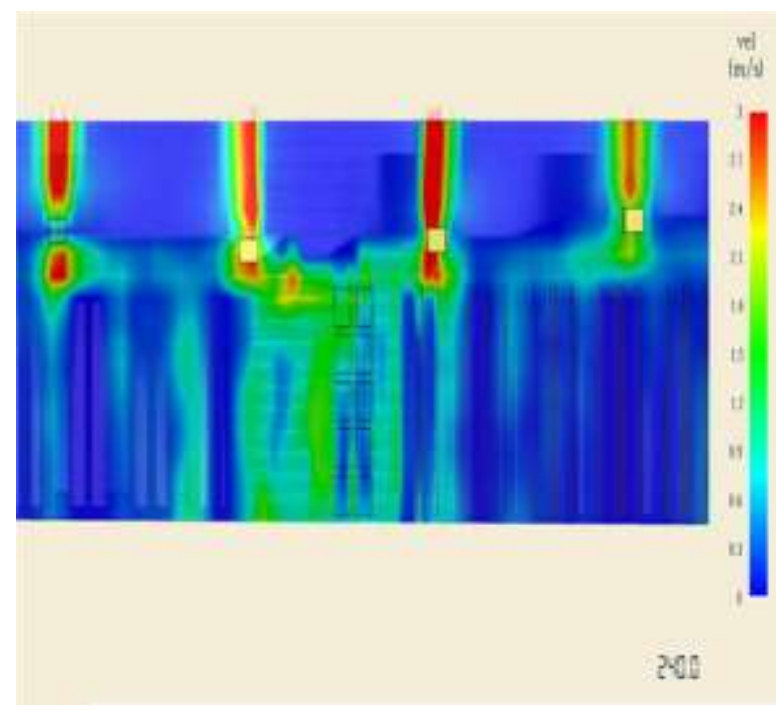

(b) Shot 2

Fig. 21 Schematic diagram shows the velocity for smoke extract fans during the fire (Scenario III). 


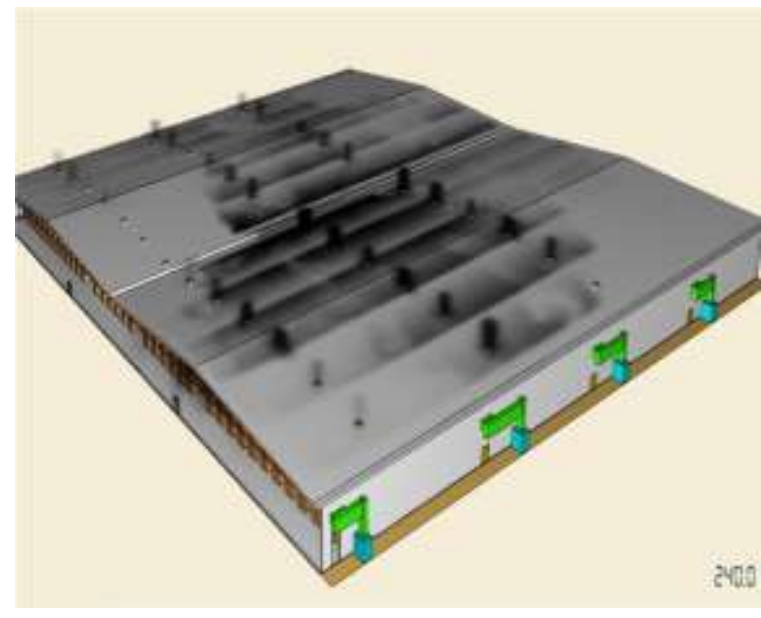

(a) Shot 1

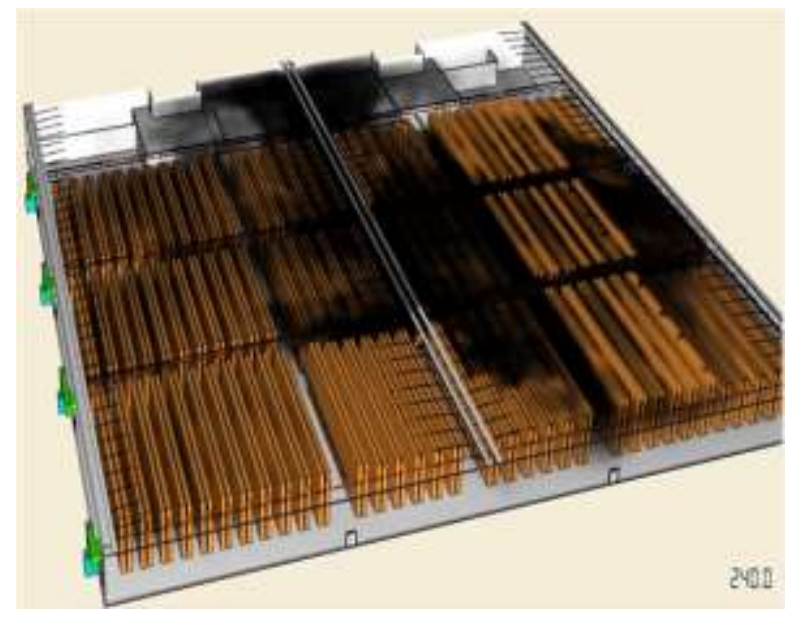

(b) Shot 1

Fig. 22 Schematic diagram shows the smoke view over the store during the fire (Scenario III).

Figures 23a, 23b shows the average temperature in escape path 1 (maximum temperature $43^{\circ} \mathrm{C}$ ), and the average temperature in escape path 2 (maximum temperature $48^{\circ} \mathrm{C}$ ), respectively

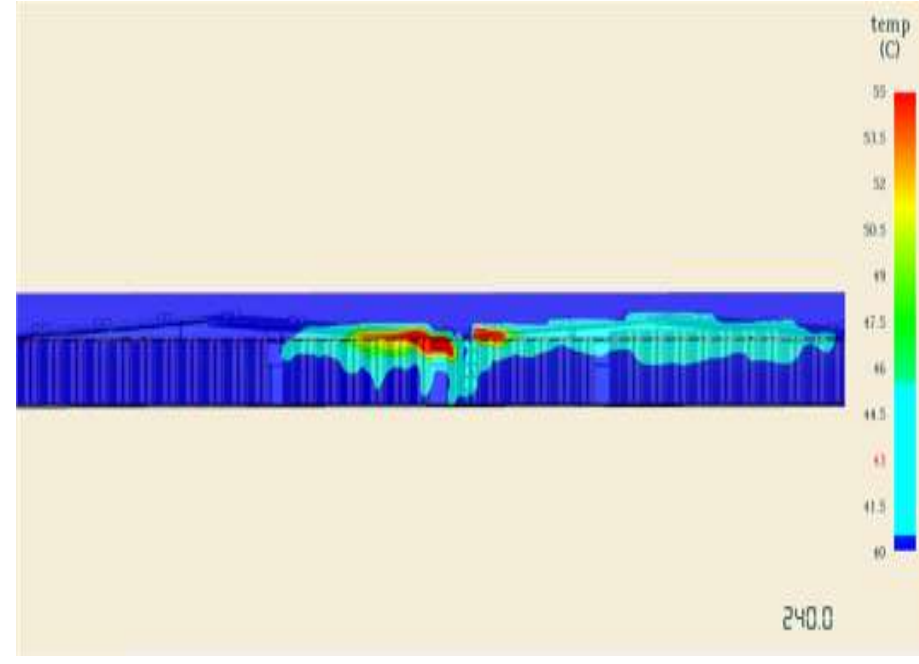

(a) Average temperature in escape path 1

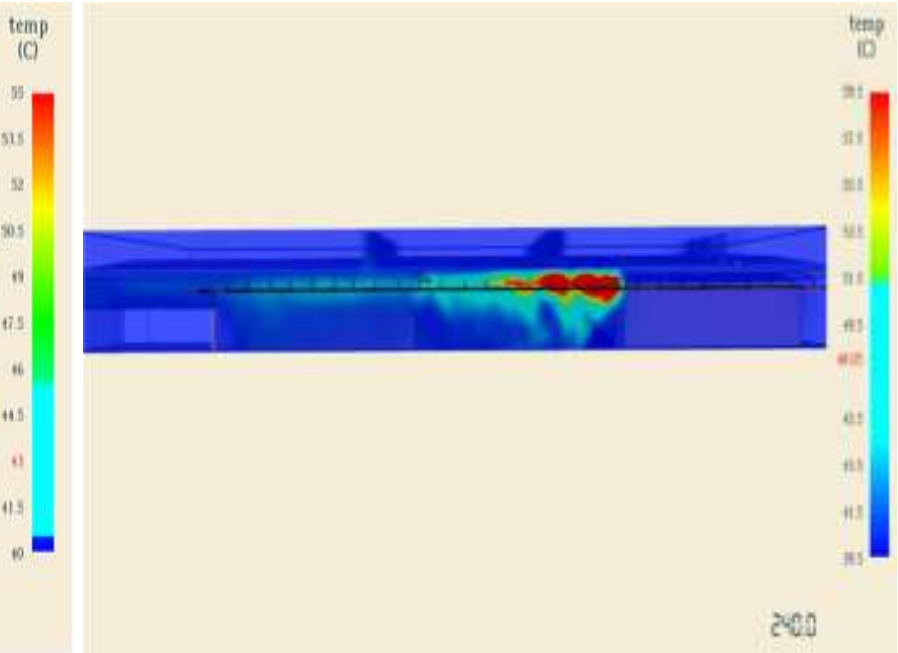

(b) Average temperature in escape path 2

Fig. 23 Cut planes shows the average temperature during the fire (Scenario III).

Figures $24 \mathrm{a}$ and $24 \mathrm{~b}$ shows effect of the sprinklers when it opened during the fire on temperature inside the store, respectively. 


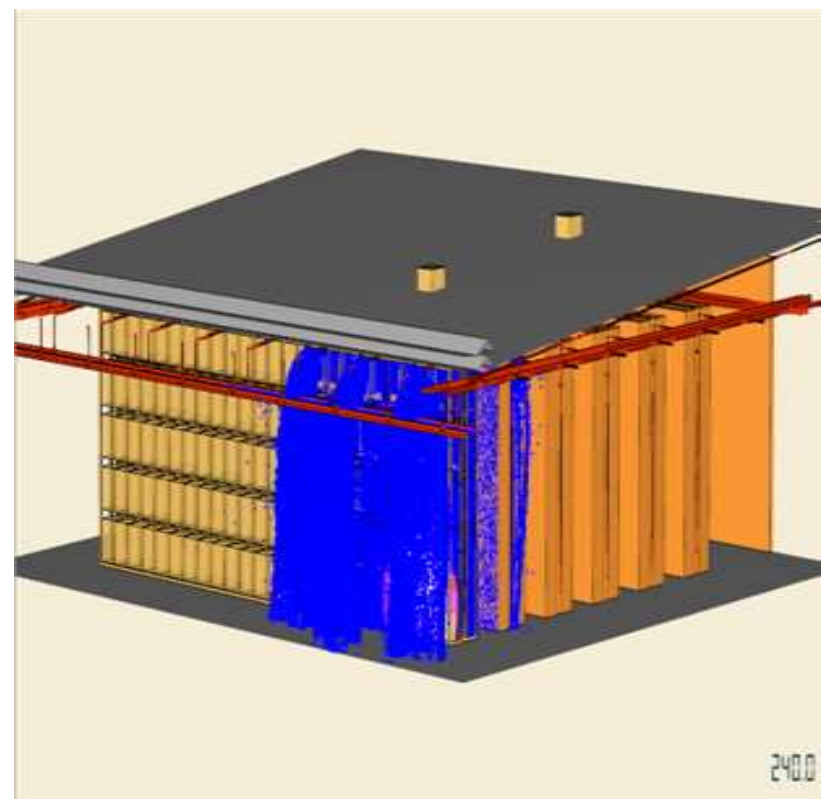

(a) Shot 1

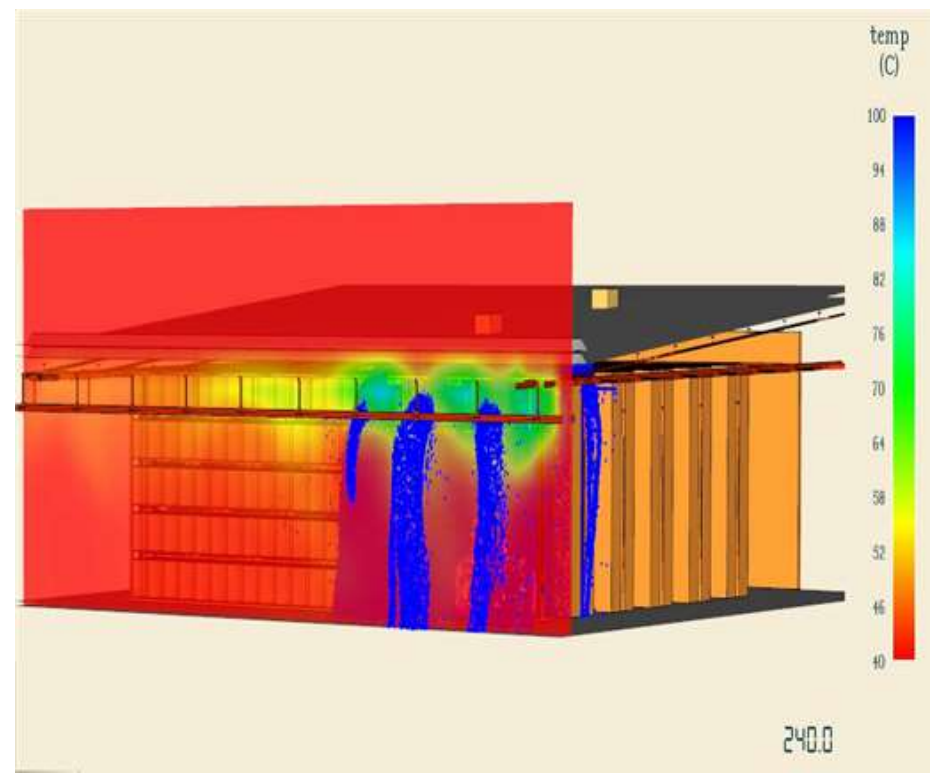

(b) Shot 2

Fig.24 Schematic diagram shows effect of the sprinklers when it opened during the fire (Scenario III). The visibility is presented in Figs. 25a and Fig. 25b, which shows the visible escape distance above the ground for path 1. The escape distance for path 2 can be found in Fig.26.

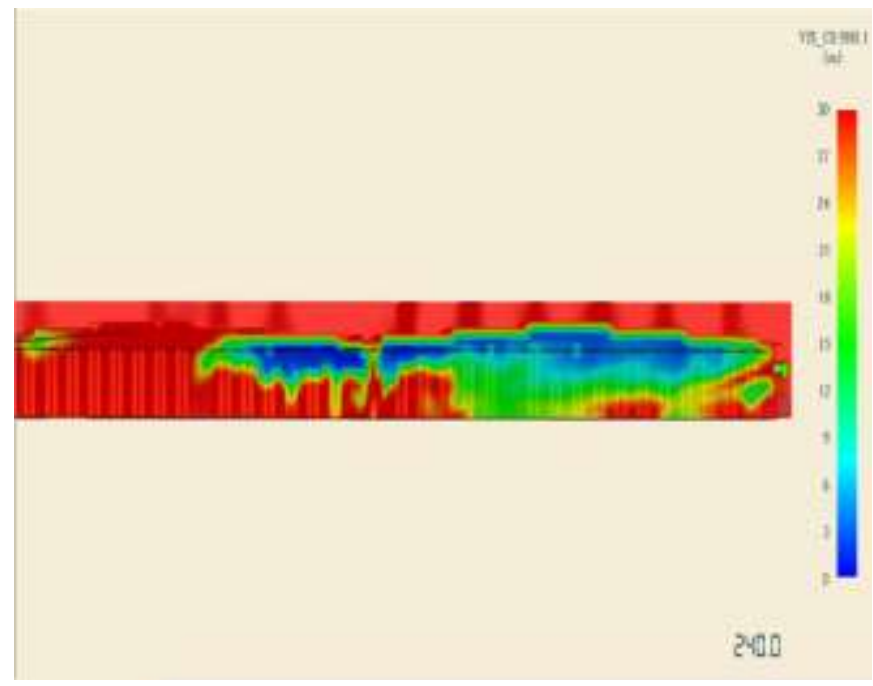

(a) 2d Cuts plane

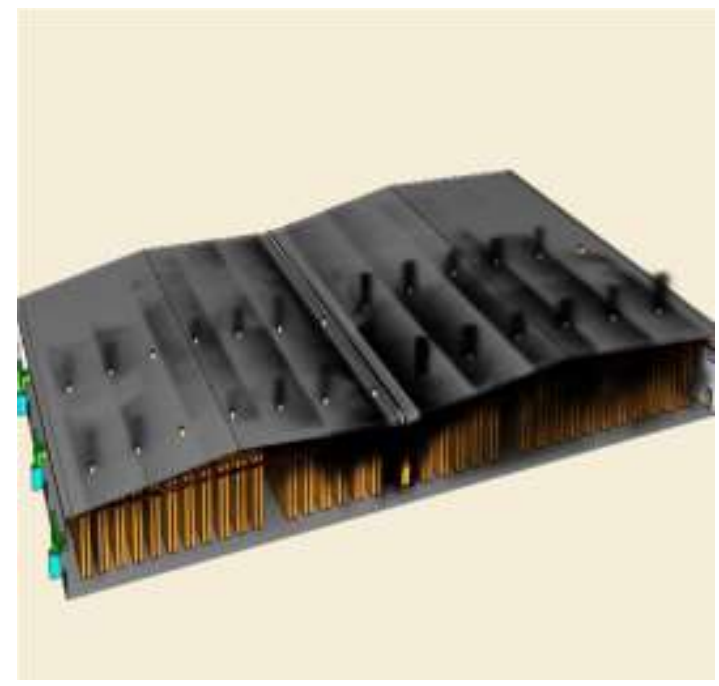

(b) different orientation

Fig. 25 Schematic diagram shows the visible distance for Escape path 1 (Scenario III). 


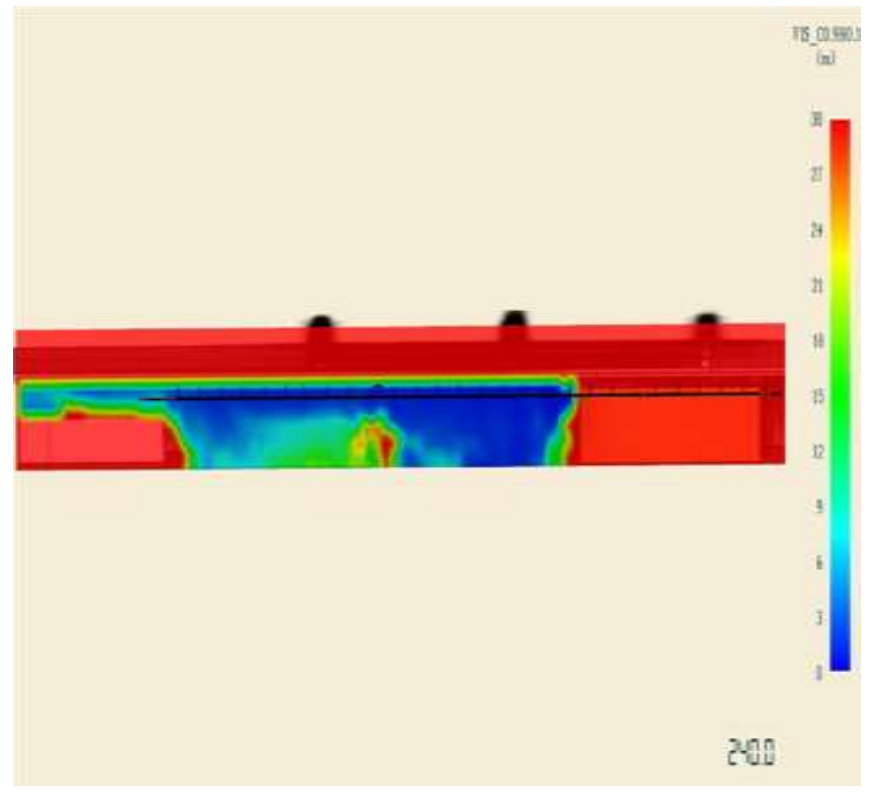

(a) shot 1

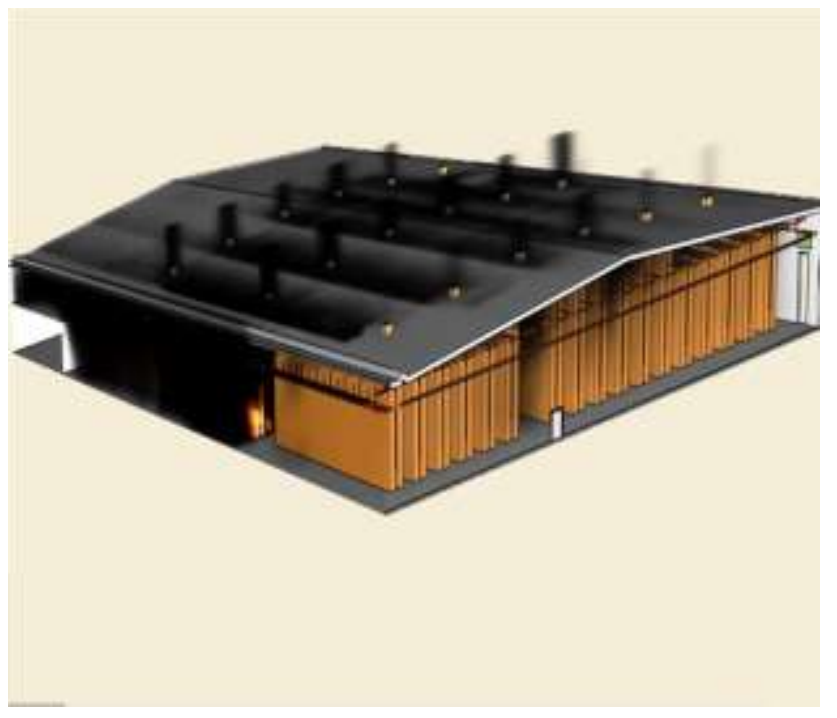

(b) shot 2

Fig. 26 Schematic diagram shows the visible distance for Escape path 2 (Scenario III).

Figures 27a. 27b shows the CO concentration in parts per million for escape path 1 , and the $\mathrm{CO}$ concentration in parts per million for escape path 2 respectively.

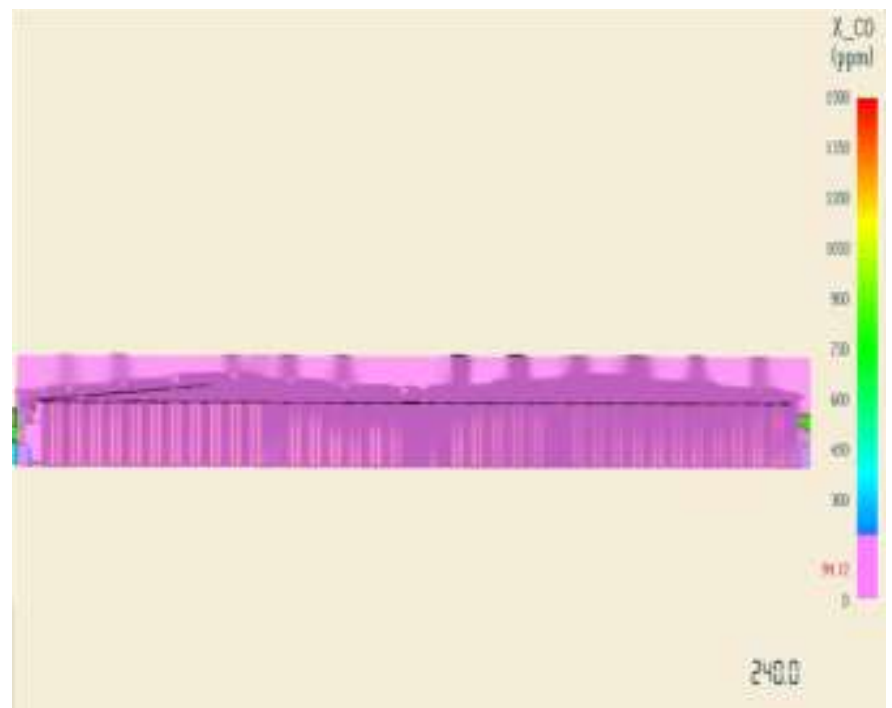

(a) For escape path 1

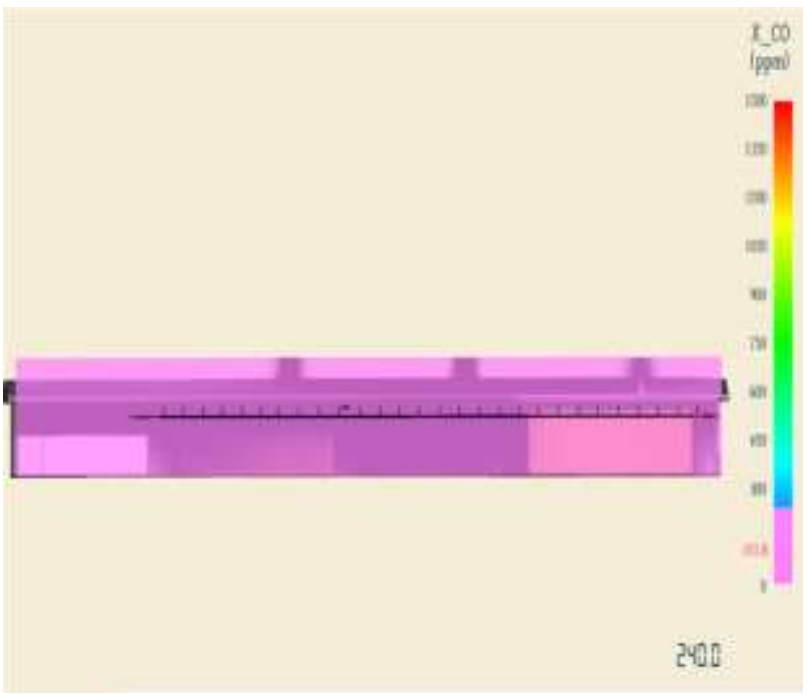

(b) For escape path 2

Fig. 27 Schematic diagram shows the CO concentration in parts per million during the fire.

\subsubsection{Conclusion on Scenario III}

Based on the FDS analysis model, the table below summarizes NFPA 92-2018 requirements. As seen from the summary, the values of various parameters are within the tolerable limits as per the standard as shown as Table 4. 
Table 4: NFPA 92-2018 requirements

\begin{tabular}{|c|c|}
\hline NFPA 92 Requirements & Results Achieved \\
\hline $\begin{array}{c}\text { Maximum air temperatures of } 60^{\circ} \mathrm{C} \text { are } \\
\text { allowed for a few seconds. }\end{array}$ & Max $58^{\circ} \mathrm{C}$ \\
\hline $\begin{array}{c}\text { Door and wall should be visible from } 10 \mathrm{~m} \\
\text { distance. }\end{array}$ & Mean $5 \mathrm{~m}$ \\
\hline $\begin{array}{c}\text { Co concentration Averaging } 1500 \mathrm{ppm} \text { or } \\
\text { less for the first } 6 \text { minutes of the exposure. }\end{array}$ & Max $112 \mathrm{ppm}$ \\
\hline
\end{tabular}

Based on this summary we can conclude that the mechanical ventilation system using the smoke extract fans and make-up fans is sufficient expect of the visibility [16] considering the parameters Defined within This work.

As a result of the increase in the smoke rate in the third scenario, which affected the visibility, the fourth scenario submit where the smoke fans and make-up fans are activated immediately after receiving the signal from the smoke detectors [11] [17].

\subsection{Racks Area Scenario After Adjusting the Operation Time of the Smoke and Make-Up Fans}

\subsubsection{Results of FDS Simulation Scenario IV}

The FDS analysis simulation done using the parameters mentioned in the previous sections (Sec. 3); the results of this simulation are summarized below. With same escape paths which was used in scenario III.

The Following figures shows the three most important parameters, temperature, Visibility, and $\mathrm{CO}$ Concentration at various locations. Figure 28 shows the heat release rates in fires as a function of time, Fig. 29 illustrates the maximum temperature in escape route as a function of time, and Fig. 30represents the visibility in escape route as a function of time.

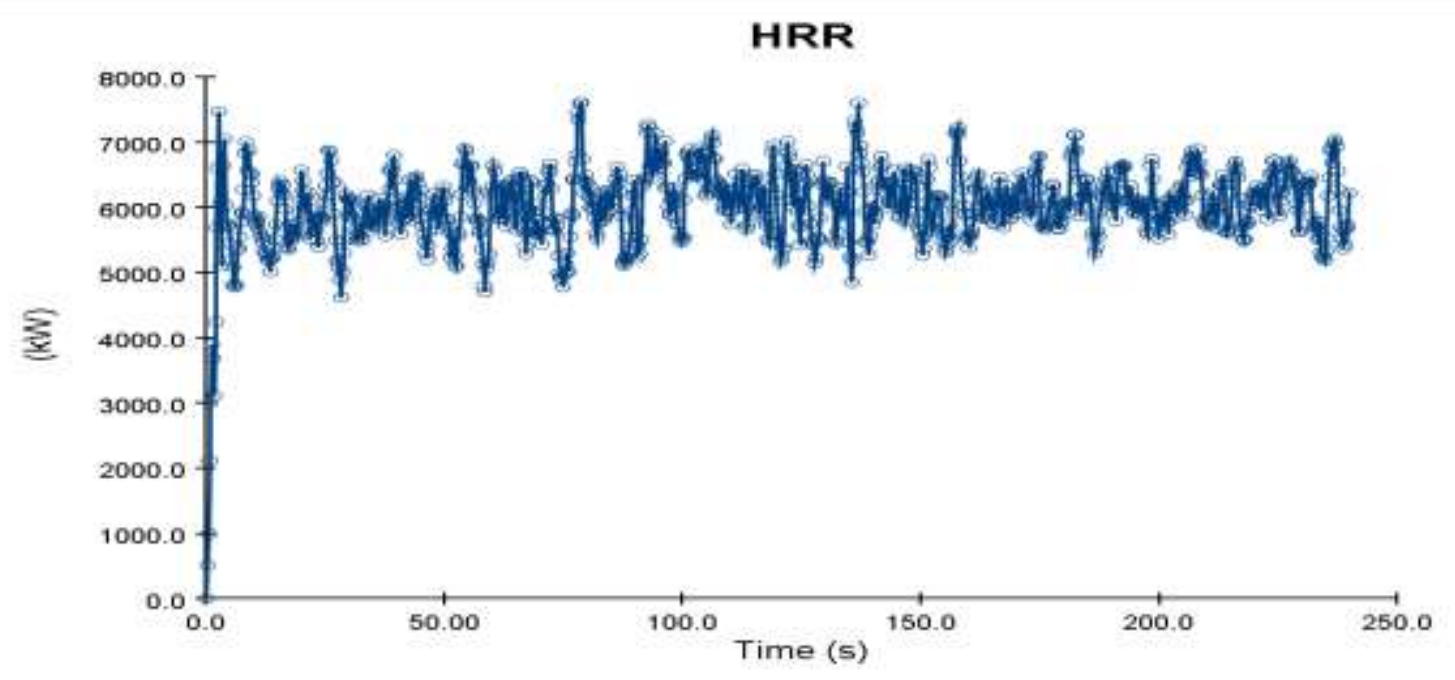

Fig. 28 The heat release rates in fires as a function of time (Scenario IV). 


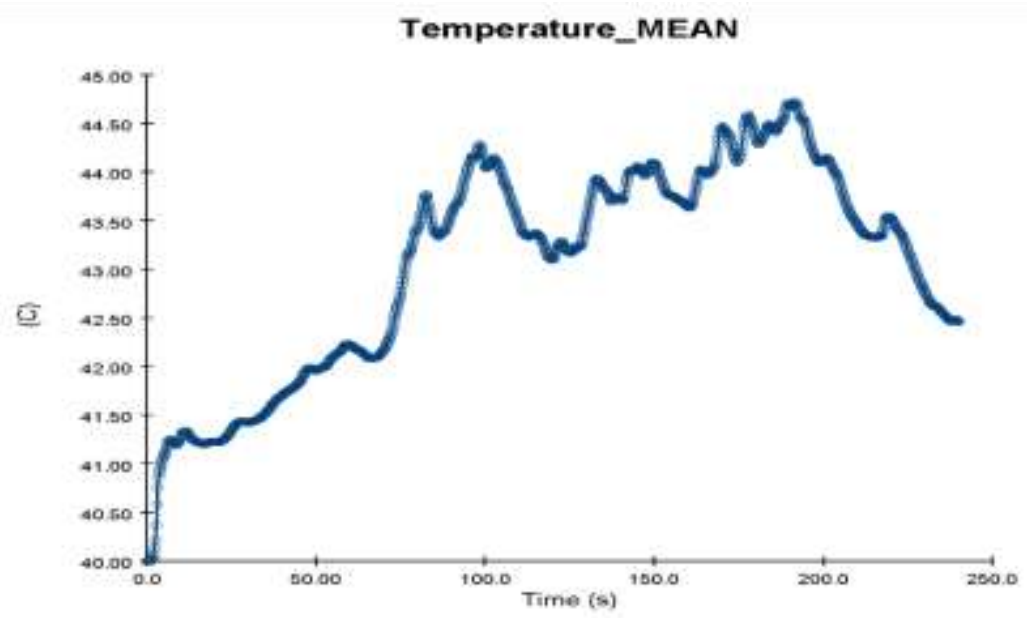

Fig. 29 The maximum temperature in escape route as a function of time (Scenario IV).

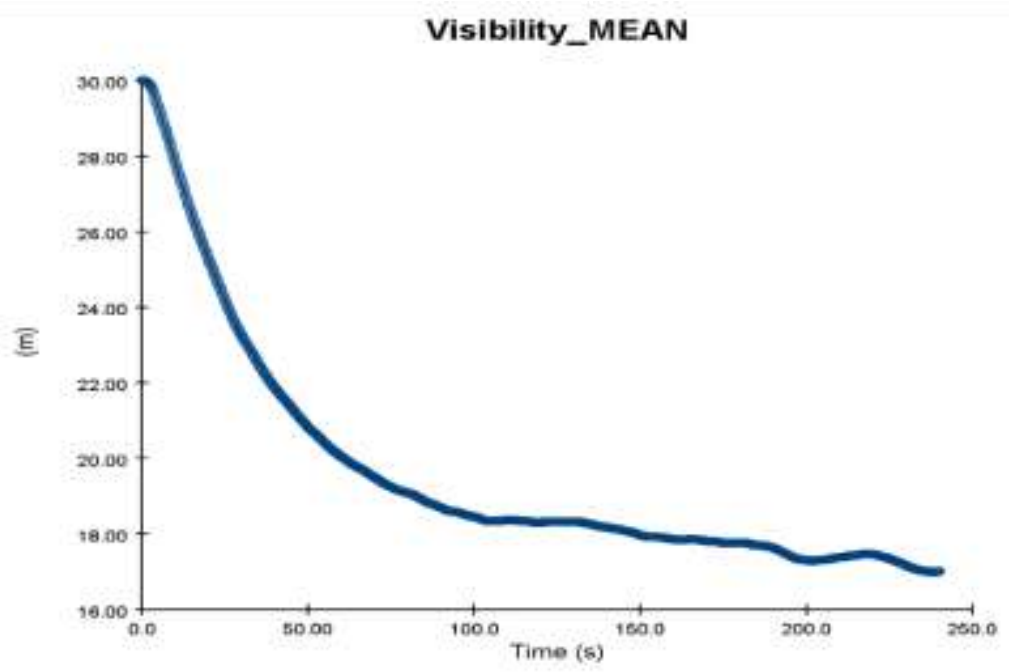

Fig. 30 The visibility in escape route as a function of time (Scenario IV).

Velocity, smoke, and temperature distribution over the store are shown in Figs. 31, 32, and 33, respectively. The make-up fresh air distribution is illustrated by Fig. 31 a, and Fig. 31b, which are the top and side view, respectively. In additional the velocity for smoke extract fans during the fire illustrated by Fig .32a, and Fig 32b. Also, the smoke path is presented in Fig. 33a and Fig. 33b, which are at different building orientations. 


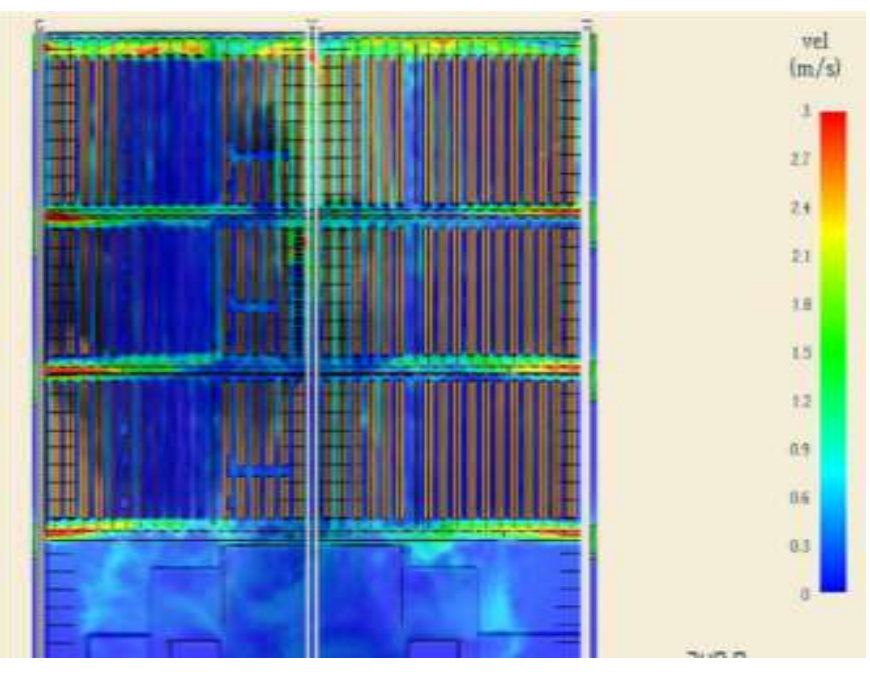

(a) Top view

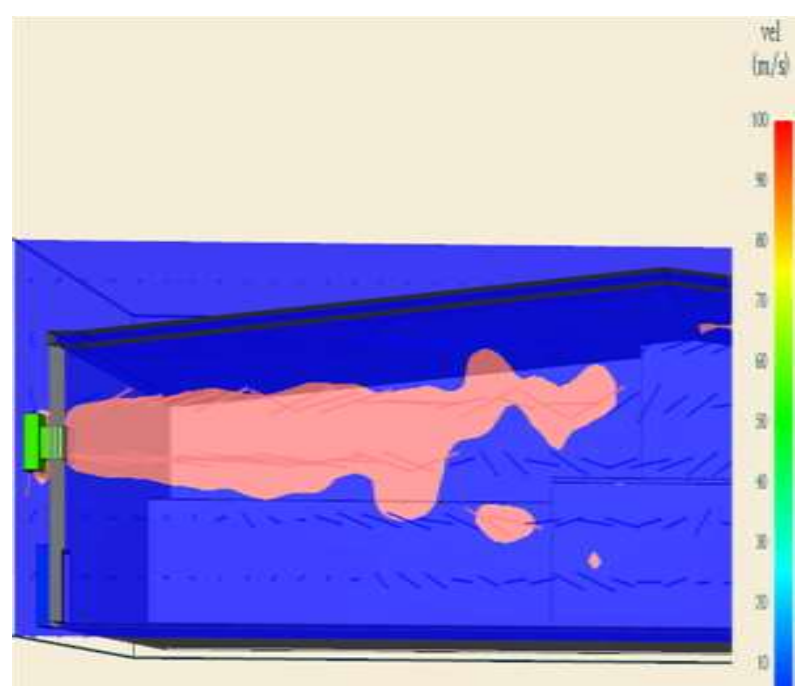

(b) Randomly selected side-section

Fig. 31 Velocity distribution of make-up fresh air fans (Scenario IV).

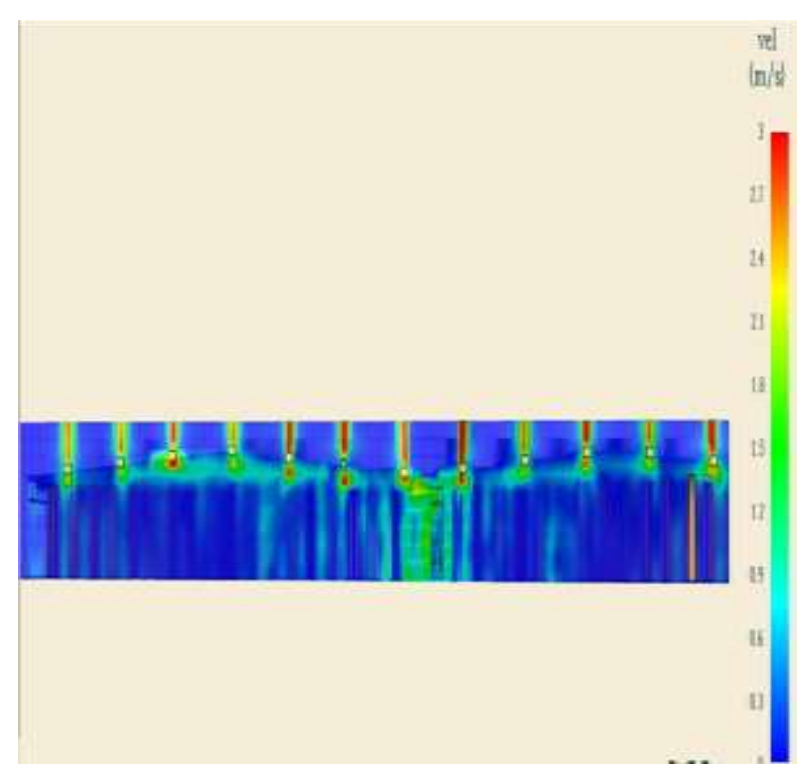

(a) Shot 1

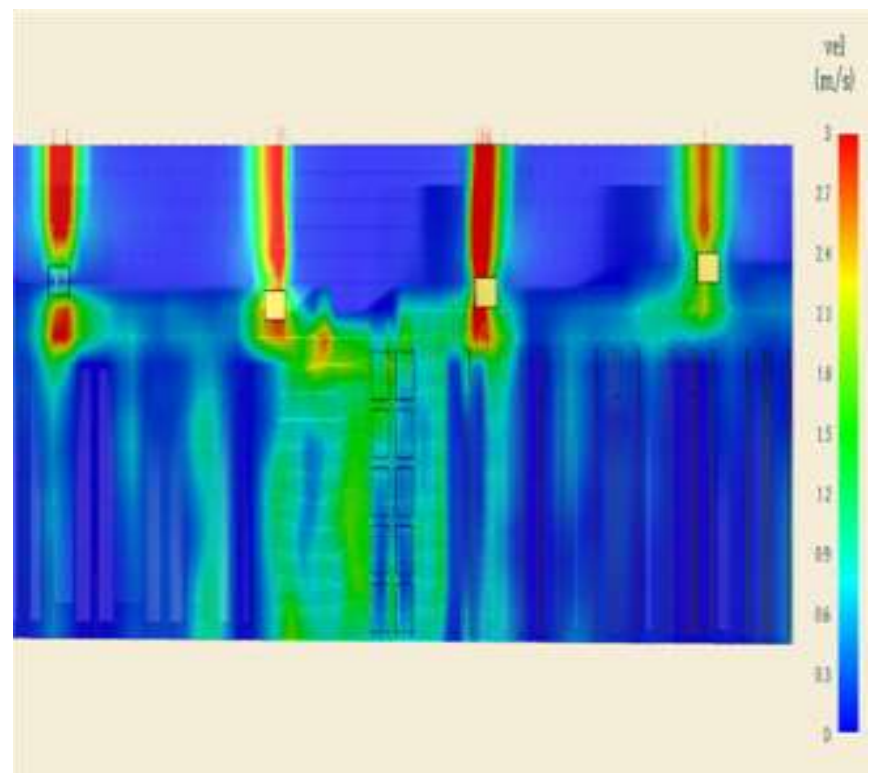

(b) Shot 2

Fig. 32 Schematic diagram shows the velocity for smoke extract fans during the fire (Scenario IV). 


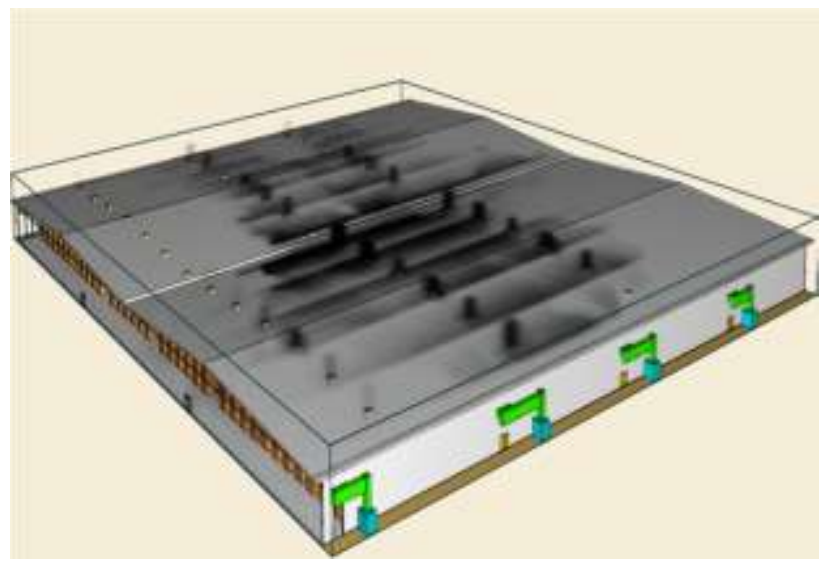

(a) Shot 1

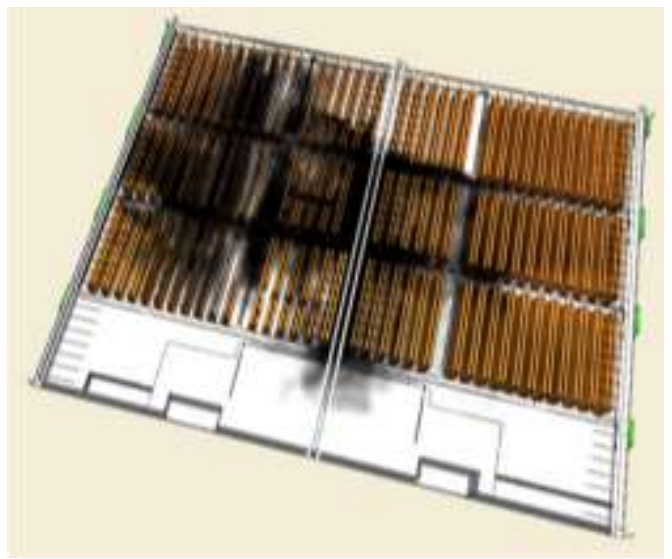

(b) Shot 1

Fig. 33 Schematic diagram shows the smoke view over the store during the fire (Scenario IV). Figures 34a, 34b shows the average temperature in escape path 1 (maximum temperature $41.57^{\circ} \mathrm{C}$ ), and the average temperature in escape path 2 (maximum temperature $44^{\circ} \mathrm{C}$ ), respectively.

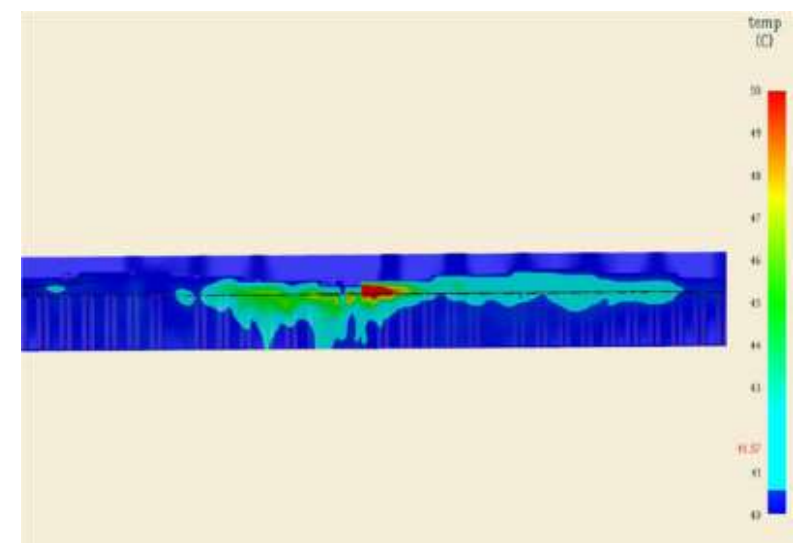

(a) Average temperature in escape path 1

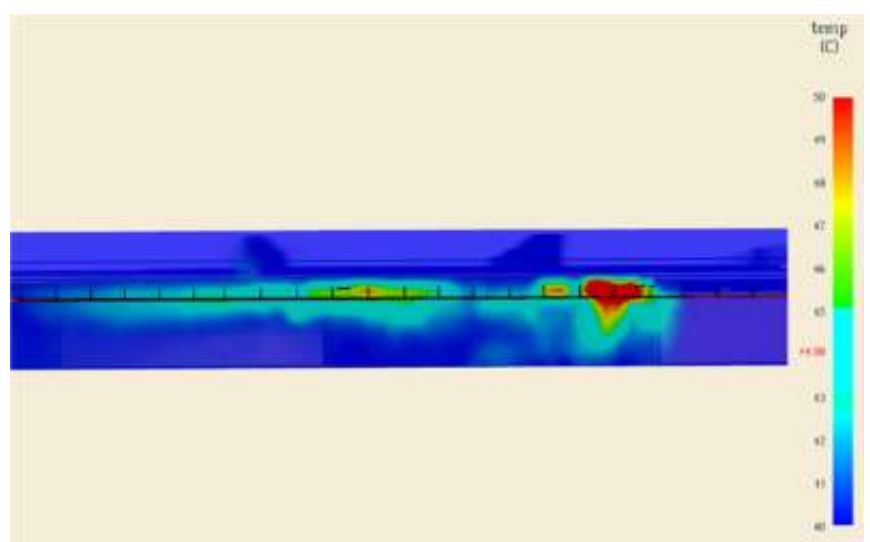

(b) Average temperature in escape path 2

Fig. 34 Cut planes shows the average temperature during the fire (Scenario IV).

Figures $35 \mathrm{a}$ and $35 \mathrm{~b}$ shows effect of the sprinklers when it opened during the fire on temperature inside the store, respectively. 


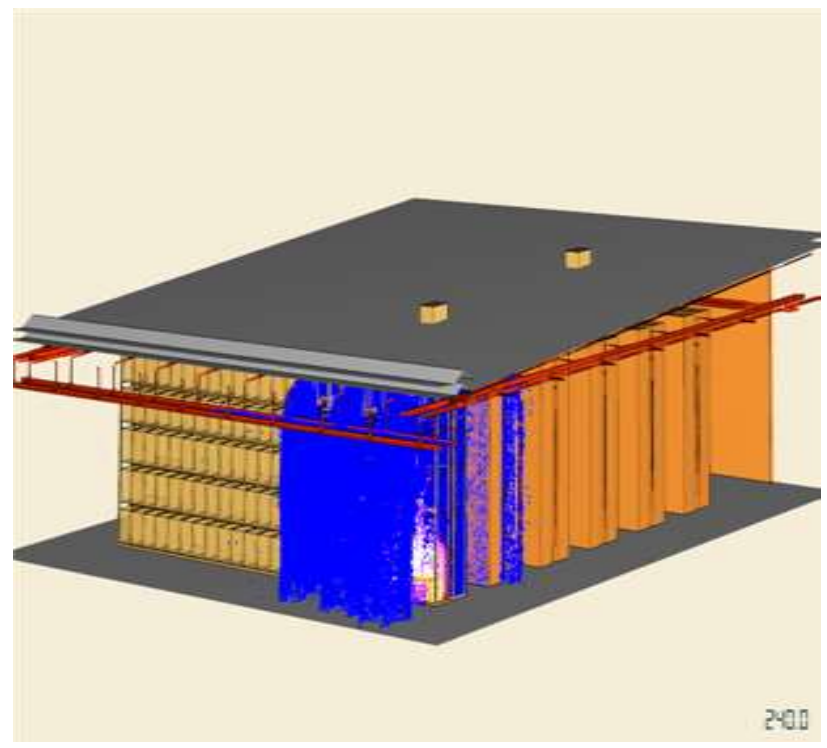

(a) Shot 1

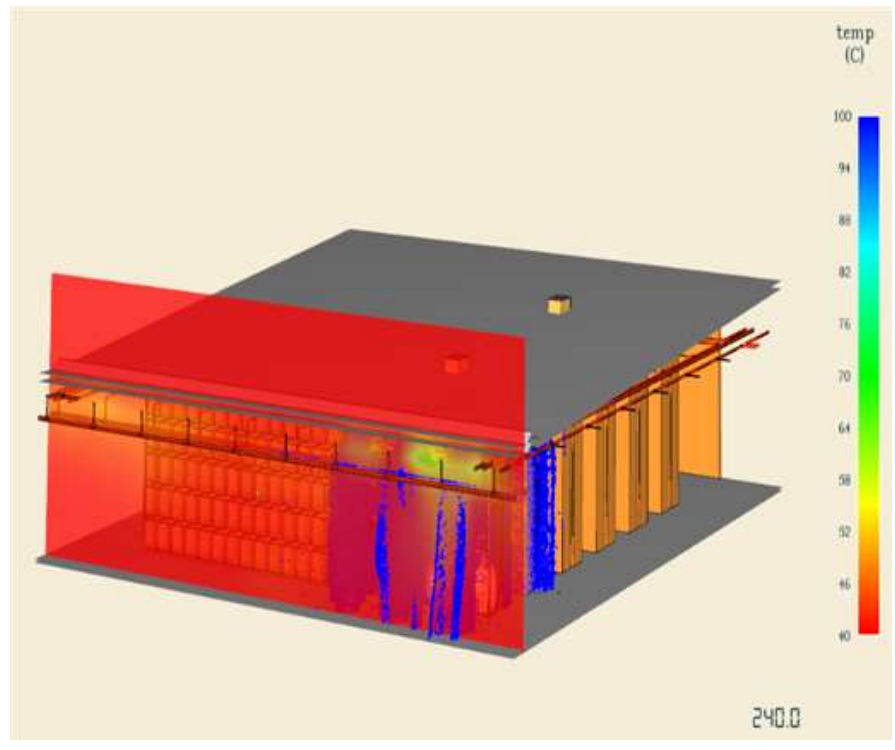

(b) Shot 2

Fig.35 Schematic diagram shows effect of the sprinklers when it opened during the fire (Scenario IV). The visibility is presented in Figs. 36a and Fig. 36b, which shows the visible escape distance above the ground for path 1. The escape distance for path 2 can be found in Fig.37.

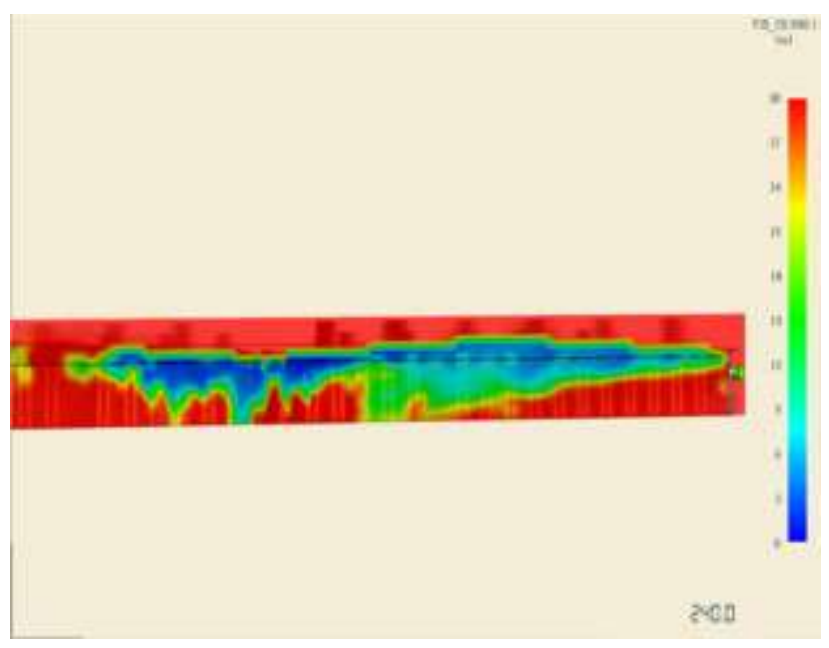

(a) 2d Cuts plane

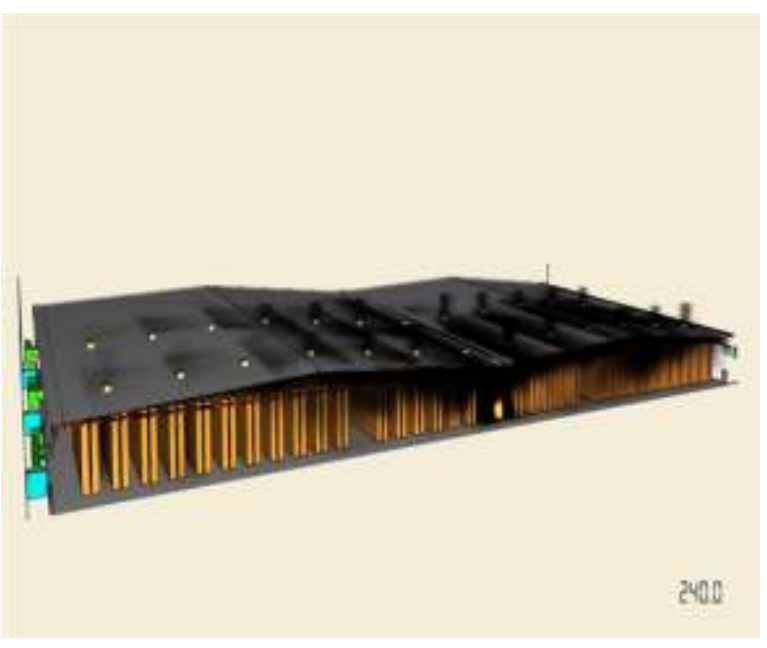

(b) different orientation

Fig. 36 Schematic diagram shows the visible distance for Escape path 1 (Scenario IV). 


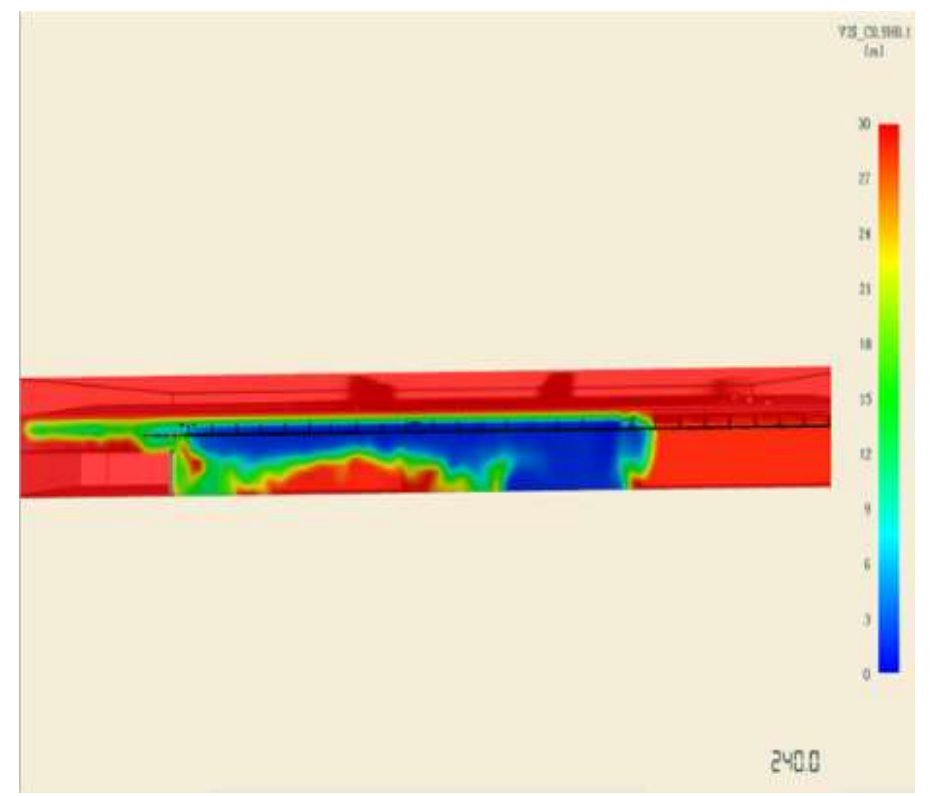

(a) shot 1

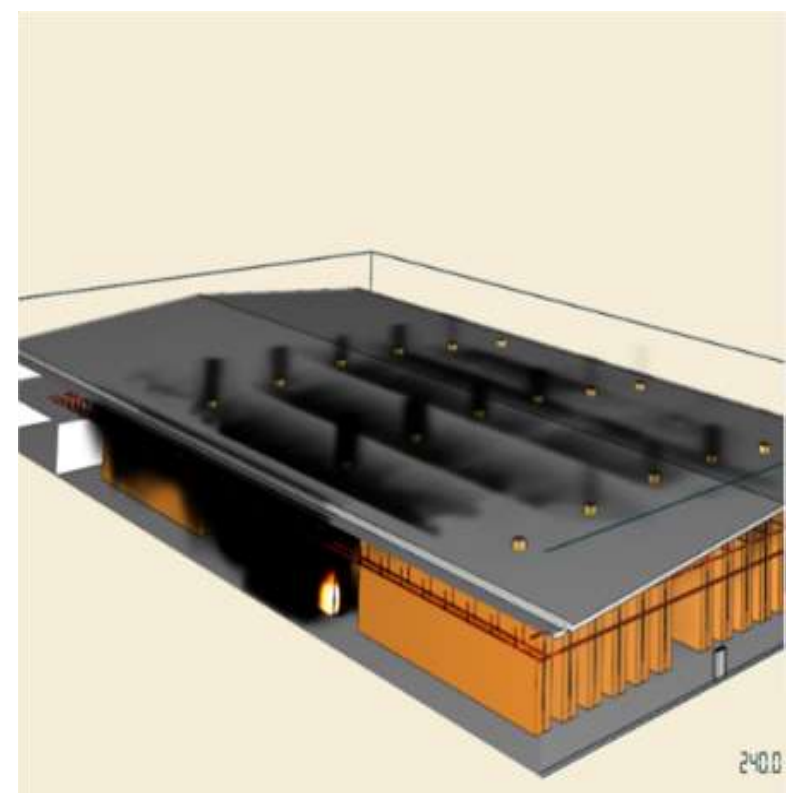

(b) shot 2

Fig. 37 Schematic diagram shows the visible distance for Escape path 2 (Scenario IV).

Figures 38a. 38b shows the CO concentration in parts per million for escape path 1 , and the $\mathrm{CO}$ concentration in parts per million for escape path 2 respectively.

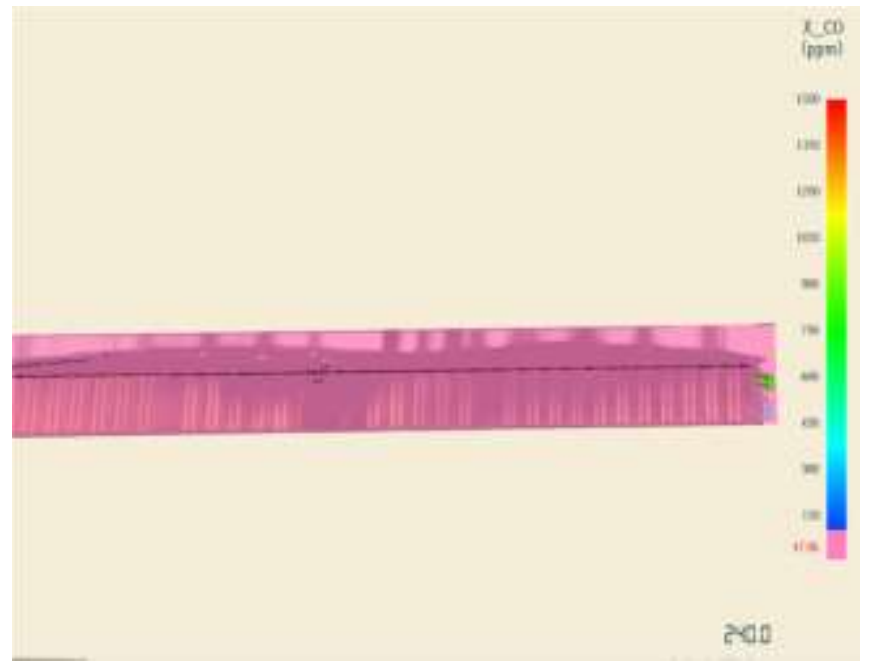

(a) For escape path 1

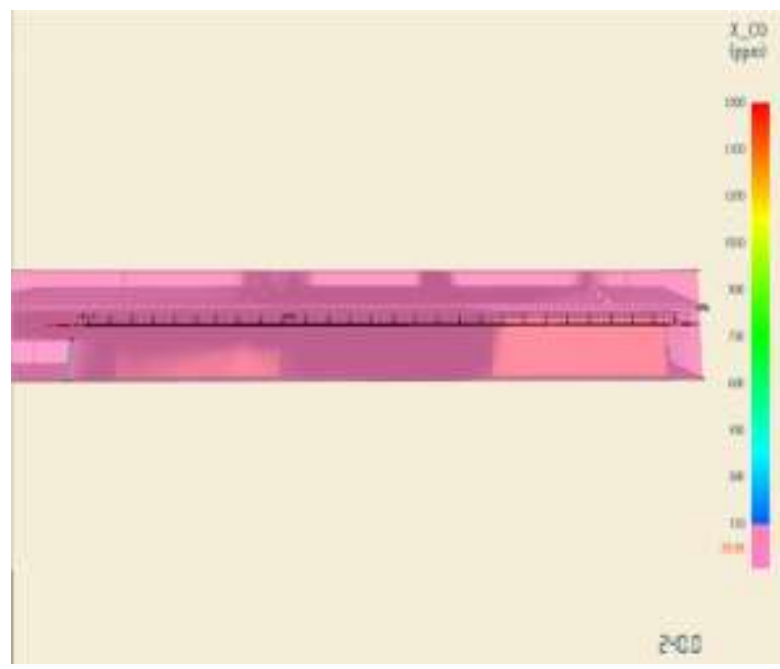

(b) For escape path 2

Fig. 38 Schematic diagram shows the $\mathrm{CO}$ concentration in parts per million during the fire.

\subsubsection{Conclusion on Scenario IV}

Based on the FDS analysis model, the table below summarizes NFPA 92-2018 requirements. As seen from the summary, the values of various parameters are within the tolerable limits as per the standard as shown as Table 5. 
Table 5: NFPA 92-2018 requirements

\begin{tabular}{|c|c|}
\hline NFPA 92 Requirements & Results Achieved \\
\hline $\begin{array}{c}\text { Maximum air temperatures of } 60^{\circ} \mathrm{C} \text { are } \\
\text { allowed for a few seconds. }\end{array}$ & Mean $44.5^{\circ} \mathrm{C}$ \\
\hline $\begin{array}{c}\text { Door and wall should be visible from } 10 \mathrm{~m} \\
\text { distance. }\end{array}$ & Mean $16 \mathrm{~m}$ \\
\hline $\begin{array}{c}\text { Co concentration Averaging } 1500 \mathrm{ppm} \text { or } \\
\text { less for the first } 6 \text { minutes of the exposure. }\end{array}$ & Mean $70.5 \mathrm{ppm}$ \\
\hline
\end{tabular}

Based on this summary we can conclude that the mechanical ventilation system using the smoke extract fans and make-up fans are sufficient considering the parameters Defined within This thesis.

\section{5- Final Conclusion}

In this research, Fire Dynamics Simulator (FDS) software was used to evaluate the smoke movement within station and tenable environment along the path of egress from a fire incident in station Completion of this analysis required development of fire scenarios, and execution of FDS computer simulations to analyze ambient temperatures and sight length (visibility) along the evacuation path.

In electrical panel room scenario, the fire material suggested was Polyurethane chair and the Fire size was $2 \mathrm{MW}$, the results of the simulation according to Table 2 were

\begin{tabular}{|c|c|}
\hline NFPA 92 Requirements & Results Achieved \\
\hline $\begin{array}{c}\text { Maximum air temperatures of } 60^{\circ} \mathrm{C} \text { are allowed for } \\
\text { a few seconds. }\end{array}$ & Max $47^{\circ} \mathrm{C}$ \\
\hline Door and wall should be visible from $10 \mathrm{~m}$ distance. & $29.5 \mathrm{~m}$ \\
\hline $\begin{array}{c}\text { Co concentration Averaging } 1500 \mathrm{ppm} \text { or less for } \\
\text { the first } 6 \text { minutes of the exposure. }\end{array}$ & Max $60 \mathrm{ppm}$ \\
\hline
\end{tabular}

In mechanical room scenario, the fire material suggested was Polyurethane sofa, and the Fire size was $3 \mathrm{MW}$, the results of the simulation according to Table 3 were

\begin{tabular}{|c|c|}
\hline NFPA 92 Requirements & Results Achieved \\
\hline $\begin{array}{c}\text { Maximum air temperatures of } 60^{\circ} \mathrm{C} \text { are allowed for a few } \\
\text { seconds. }\end{array}$ & Max $49^{\circ} \mathrm{C}$ \\
\hline Door and wall should be visible from 10m distance. & $18 \mathrm{~m}$ \\
\hline $\begin{array}{c}\text { Co concentration Averaging } 1500 \mathrm{ppm} \text { or less for the } \\
\text { first } 6 \text { minutes of the exposure. }\end{array}$ & Max $80 \mathrm{ppm}$ \\
\hline
\end{tabular}

In racks area scenario, the fire material suggested was wood constructions and the Fire size was $6 \mathrm{MW}$, the results of the simulation according to Table 4were 
H.sadek/Engineering Research Journal 169 (March 2021/M38_M67)

\begin{tabular}{|c|c|}
\hline NFPA 92 Requirements & Results Achieved \\
\hline $\begin{array}{c}\text { Maximum air temperatures of } 60^{\circ} \mathrm{C} \text { are allowed for a } \\
\text { few seconds. }\end{array}$ & Max $58^{\circ} \mathrm{C}$ \\
\hline Door and wall should be visible from 10m distance. & Mean $5 \mathrm{~m}$ \\
\hline $\begin{array}{c}\text { Co concentration Averaging } 1500 \text { ppm or less for the } \\
\text { first } 6 \text { minutes of the exposure. }\end{array}$ & Max $112 \mathrm{ppm}$ \\
\hline
\end{tabular}

And as a result of the increase in the smoke rate in this scenario, which affected the visibility, the fourth scenario submit where the smoke fans and make-up fans are activated immediately after receiving the signal from the smoke detectors, and the results of the simulation according to Table 5 were

\begin{tabular}{|c|c|}
\hline NFPA 92 Requirements & Results Achieved \\
\hline $\begin{array}{c}\text { Maximum air temperatures of } 60^{\circ} \mathrm{C} \text { are allowed for } \\
\text { a few seconds. }\end{array}$ & Mean $44.5^{\circ} \mathrm{C}$ \\
\hline $\begin{array}{c}\text { Door and wall should be visible from } 10 \mathrm{~m} \\
\text { distance. }\end{array}$ & Mean $16 \mathrm{~m}$ \\
\hline $\begin{array}{c}\text { Co concentration Averaging } 1500 \text { ppm or less for } \\
\text { the first } 6 \text { minutes of the exposure. }\end{array}$ & Mean $70.5 \mathrm{ppm}$ \\
\hline
\end{tabular}

Based on this conclusion we can get the optimal design of smoke extraction methods in this large Store and the mechanical ventilation system using the smoke extract fans and make-up fans is sufficient considering the parameters Defined within This work.

\section{REFERENCES}

[1] Alarie Y., Toxicity of fire smoke. Crit Rev Toxicol (2002);32: 259-289.

[2] Chow CL, Chow WK and Lu ZA., Assessment of smoke toxicity of building materials. Fire Saf Sci (2004); 6: 3a-31.

[3] Lizhong Yang, Computational fluid dynamics-assisted smoke control system design for solving fire uncertainty in buildings (2019); P.1-5

[4] T. Yamana, T. Tanaka, Smoke control in large scale spaces, Fire Sci. Technol. 5 (1) (1985) 41-54.

[5] W.K. Chow, B. Yao, M.Y. Ng, Application of water mist fire suppression systems in small retail shops, J. Fire Sci. 20 (6) (2002) 479-503.

[6] J.A. Milke, Evaluating the Smoke Hazard from Fires in Large Spaces, International Journal on Engineering Performance-Based Fire Codes, Volume 2, Number 3, p.94-103, (2000).

[7] McGratton, K.B., Baum, H.R., Rehm, R.G., Hammins, A., Forney, G.P. and Prasad, K. Fire Dynamics Simulator (Version 3) - Technical Reference Guide, NISTIR 6783, Gaithersburg, MD: National Institute of Standards and Technology. (2002).

[8] Klote J.H, Milke J.A., Principles of Smoke Management (2002).

[9] Hadjisophocleous, G.V., and McCartney., "Guidelines for the Use of CFD Simulations for Fire and Smoke Modelling", ASHRAE Transactions, DE-05-7-3 pp. 583-594, (2005). 
[10] NFPA 921, Guide for Fire and Explosion Investigations (2017), Table 5.6.3.

[11] NFPA 92, Standard for Smoke Control Systems (2018)

[12] FIRE PROTECTION HANDBOOK VOLUMES I and II (20 ${ }^{\text {th }}$ edition).

[13] NFPA 101, Life Safety Code (2016), Table 7.3.1.2.

[14] NFPA 101, Life Safety Code (2006).

[15] CIBSE, Chartered Institution of Building Services Engineers Lx- Lux dB- Decibels Guide E (Fire Engineering) (2003), Section 10.8.3 - i.e., Finite Area Source- Circle or Rectangle.

[16] ISO 21927-1, EN 12101-1, Specification for smoke barriers.

[17] Egyptian Code of Fire (2009), Part two 2/3/4/3/3 Response Time. 